\title{
Comparative study on the physical entrapment of soy and mushroom proteins on the durability of bacterial cellulose bio-leather
}

\author{
Hyunjin Kim • Ji Eun Song $\cdot$ Hye Rim Kim $\mathbb{B}$
}

Received: 30 September 2020/ Accepted: 18 January 2021 / Published online: 7 February 2021

(C) The Author(s) 2021

\begin{abstract}
This study aimed to develop eco-friendly bacterial cellulose (BC) bio-leather with improved durability using plant-based proteins, namely soy protein isolate (SPI) and mushroom protein (MP), which were physically entrapped inside the BC, respectively. The amounts of the plant-based proteins were determined by evaluating the tensile strength of $\mathrm{BC}$ bio-leather, and were found to be $20 \mathrm{wt} \%$ and $50 \mathrm{wt} \%$ of BC for SPI and MP, respectively. The enhanced properties of mechanical strength and durability of BC bio-leather were measured in terms of changes in water resistance, tensile strength, flexibility, crease recovery, and dimensional stability. The durability of BC was improved after the entrapment of proteins, and moreover, the durability of BC entrapped with plant-based proteins was further improved by the addition of glycerol. Especially, BC entrapped with MP and glycerol had better water resistance, tensile strength, flexibility, and crease recovery compared to cowhide leather. The chemical and physical structures of BC bio-leathers were studied using Fourier transform-infrared spectroscopy, X-ray diffraction, field-
\end{abstract}

H. Kim · H. R. Kim $(\bowtie)$

Department of Clothing and Textiles, Sookmyung

Women's University, Seoul, South Korea

e-mail: khyerim@sookmyung.ac.kr

J. E. Song $(\bowtie)$

Department of Fashion and Clothing, Seowon University,

Cheongju, Chungbuk, South Korea

e-mail: songjieun14@seowon.ac.kr emission scanning electron microscopy, and energy dispersive X-ray spectroscopy analyses. From the results, it was confirmed that $\mathrm{BC}$ entrapped with $\mathrm{MP}$ and glycerol could be a suitable leather substitute.

Keywords Bacterial cellulose $\cdot$ Bio-leather $\cdot$ Plantbased protein $\cdot$ Soy protein isolate $\cdot$ Mushroom protein - Durability

\section{Introduction}

Leather is a natural fabric material obtained from skins of animals (Stepanova et al. 2017). The treatment process of leather is highly complicated with various steps (Zarlok et al. 2014). Especially, tanning is an essential treatment process in the leather industry since it prevents the degradation of leather, and thus, the quality of leather can be maintained for a long period of time (Sudha et al. 2009). In the tanning process, however, toxic chemicals such as metal salts and hexavalent chromium are used, and the decomposition of protein wastes causes serious odor (Kanagaraj et al. 2006). Moreover, the supply of the leather is currently decreasing due to the animal protection movements, and the demand for artificial leather or eco-friendly bio-leather is increasing with the advent of vegans (Kim et al. 2017). 
Bio-leather is a sustainable biomaterial derived from natural sources such as plants and microorganisms, making it environmentally friendly and biodegradable, thus helping reduce textile waste (Garcia and Prieto 2019). According to the previous study, the general sources for bio-leather include natural latex, pineapple, mushroom, jellyfish, and bacterial cellulose (BC) (Kim et al. 2017; De Santa Costa et al. 2017). This study is focused on BC to develop the bio-leather.

$\mathrm{BC}$ is an eco-friendly cellulose material produced by Acetobacter xylinus (Kim et al. 2020a). Since BC is made of a fibrous three-dimensional nanostructure, it has excellent advantages as a bio-leather: It possesses high purity, high crystallinity and polymerization degree, and good water-holding capacity (Kim et al. 2020b); Altering the fermentation conditions can result in BC with excellent moldability, biodegradability, and biocompatibility (Song et al. 2020); Moreover, unlike animal leather, additional processes such as tanning and graining are not necessary for BC bio-leather.

However, the high water-holding capacity of BC has several drawbacks. Its hydrophilicity causes poor rehydration and durability of $\mathrm{BC}$ bio-leather, and when exposed to moist or wet conditions, BC loses its shape and strength (Song et al. 2020).

In this study, to overcome these aforementioned drawbacks, BC bio-leather is modified by physical entrapment of proteins, which are naturally derived materials, and are non-toxic and biodegradable (Wang et al. 2016). Proteins have shown to improve the mechanical properties of the cellulose composite material owing to their structural properties and high molecular binding potential (Ou et al. 2004; Zhou et al. 2008). Among them, this study is focused on plant-based proteins such as soy protein isolate (SPI) and mushroom protein (MP). SPI and MP contain polar amino acids having carboxyl and amide groups so that they can easily react with the hydroxyl groups in BC, making it easily modifiable (Tian et al. 2018; Senapati and Sarkar 2014; Kayode et al. 2015). In addition, they are inexpensive and can be easily obtained due to their abundance (Xu et al. 2019; Tian et al. 2016). Previous studies have also used SPI to modify BC (Zhang et al. 2020; Guo et al. 2018; Liu et al. 2017; Wang et al. 2017). However, in previous studies mentioned above, BC was ground or smashed, mixed with SPI, and then freeze-dried or dried to become a stabilized film or foam. These modification methods are complicated because they require additional steps to change the shape of BC. Instead, the physical entrapment method is employed in this study to entrap proteins directly inside $\mathrm{BC}$ without changing the shape of $\mathrm{BC}$. This method not only improves the durability of $\mathrm{BC}$, but also minimizes the modification process of $\mathrm{BC}$.

Therefore, the aim of this study is to develop two types of eco-friendly BC bio-leathers by physically entrapping plant-based proteins, namely SPI and MP, respectively, and compare their durability. To enhance the processability of SPI and MP, glycerol was added (Tian et al. 2012). The amount of proteins is determined by observing the change in the tensile strength. Next, the durability and mechanical properties of BC bio-leathers are measured by parameters such as water resistance, tensile strength, etc. and compared with cowhide leather of similar thickness. Lastly, chemical and physical structures of BC bioleathers are evaluated using Fourier-transform infrared spectroscopy (FT-IR), X-ray diffraction (XRD), field-emission scanning electron microscopy (FESEM), and energy dispersive X-ray spectroscopy (EDX).

\section{Materials and methods}

\section{Materials}

Glucose, hydrogen peroxide $\left(\mathrm{H}_{2} \mathrm{O}_{2}, 34.5 \%\right)$, sodium hydroxide ( $\mathrm{NaOH}$, beads), acetic acid, glycerol, and $1 \mathrm{~N} \mathrm{NaOH}$ solution were purchased from Duksan Pure Chemical Co., Ltd. (Seoul, Korea). Kombucha SCOBY was obtained by GetKombucha (CO, USA). Yeast extract and peptone were obtained from BD Biosciences (San Jose, CA, USA). Soy protein isolate was purchased from Avention (Incheon, Korea). Shiitake mushroom powder (food grade) was purchased from The Yeondu (Uijeongbu, Korea). All chemical reagents were used as received.

Production of BC bio-leather

$\mathrm{BC}$ bio-leather was produced according to the procedure reported by Han et al. (2018) followed by washing, bleaching, and swelling pretreatments (Han et al. 2018; Song et al. 2017). Briefly, glucose was 
used as a carbon source $(20 \mathrm{~g} / \mathrm{L})$, and a mixture of peptone and yeast extract powders was used as a nitrogen source $(5 \mathrm{~g} / \mathrm{L}$ for each) to produce the HS medium. Kombucha SCOBY was added in the HS medium in a liquor ratio of 1:7 and statically cultured at $26{ }^{\circ} \mathrm{C}$ for 8 days to produce $\mathrm{BC}$ with a thickness of $1 \mathrm{~cm}$. BC was then washed with $3 \% \mathrm{NaOH}$ solution at $25^{\circ} \mathrm{C}$ for $90 \mathrm{~min}$ with shaking at $50 \mathrm{rpm}$, neutralized with distilled water, and adjusted to $\mathrm{pH} 3.0$ using acetic acid for $30 \mathrm{~min}$ with shaking at $50 \mathrm{rpm}$. Subsequently, BC was bleached with a $5 \% \mathrm{H}_{2} \mathrm{O}_{2}$ solution at $90{ }^{\circ} \mathrm{C}$ for $60 \mathrm{~min}$ with shaking at $110 \mathrm{rpm}$, swelled with an $8 \% \mathrm{NaOH}$ solution in a liquor ratio of 1:10 (w/v) for $30 \mathrm{~min}$ in an ultrasonic bath (UC-20; JEIO TECH Co., Daejeon, Korea), and neutralized with acetic acid solution by adjusting the $\mathrm{pH}$ level of the solution to $\mathrm{pH}$ 3.0.

Physical entrapment of plant-based proteins in BC bio-leather

Plant-based proteins such as SPI and MP were entrapped inside the produced BC bio-leather separately. Figure 1 describes the production method of BC bio-leathers.

First, to determine the amount of SPI and MP, varied amounts of SPI or MP in the range of 10 to $60 \mathrm{wt} \%$ (weight \%) of BC bio-leather were added to distilled water with a fabric-to-liquor ratio of 1:10. The determined amount of SPI and MP was evaluated by the change in the tensile strength of $\mathrm{BC}$ bio-leather according to ISO 13934-2:2014 (Tensile properties of fabrics-Determination of maximum force using the grab method). To find out whether the effects of amounts of SPI and MP on the tensile strength of BC bio-leathers were statistically significant or not, we calculated $95 \%$ confidence intervals.

The $95 \%$ confidence interval was calculated by the following Eq. (1):

$$
\begin{aligned}
95 \% \text { confidence interval }= & \overline{\mathrm{X}}-1.96 \frac{\sigma}{\sqrt{\mathrm{n}}} \leq \mu \leq \overline{\mathrm{X}} \\
& +1.96 \frac{\sigma}{\sqrt{\mathrm{n}}}
\end{aligned}
$$

where $\bar{X}$ denotes the mean of samples, $\sigma$ denotes the standard deviation, $\mathrm{n}$ denotes the number of samples, and $\mu$ denotes the mean of a sample group.

The amount of glycerol, which was $30 \mathrm{wt} \%$ of BC bio-leather, was used to improve the processability of proteins. The resulting solutions were then ultrasonicated for $30 \mathrm{~min}$ at $25{ }^{\circ} \mathrm{C}$ to obtain uniform mixtures. Next, the solutions were subjected to denaturation. The $\mathrm{pH}$ levels of the solutions were adjusted to 10 $( \pm 0.5)$ using $1 \mathrm{~N} \mathrm{NaOH}$ solution and the solutions were shaken in a shaking water bath (BS-31; JEIO

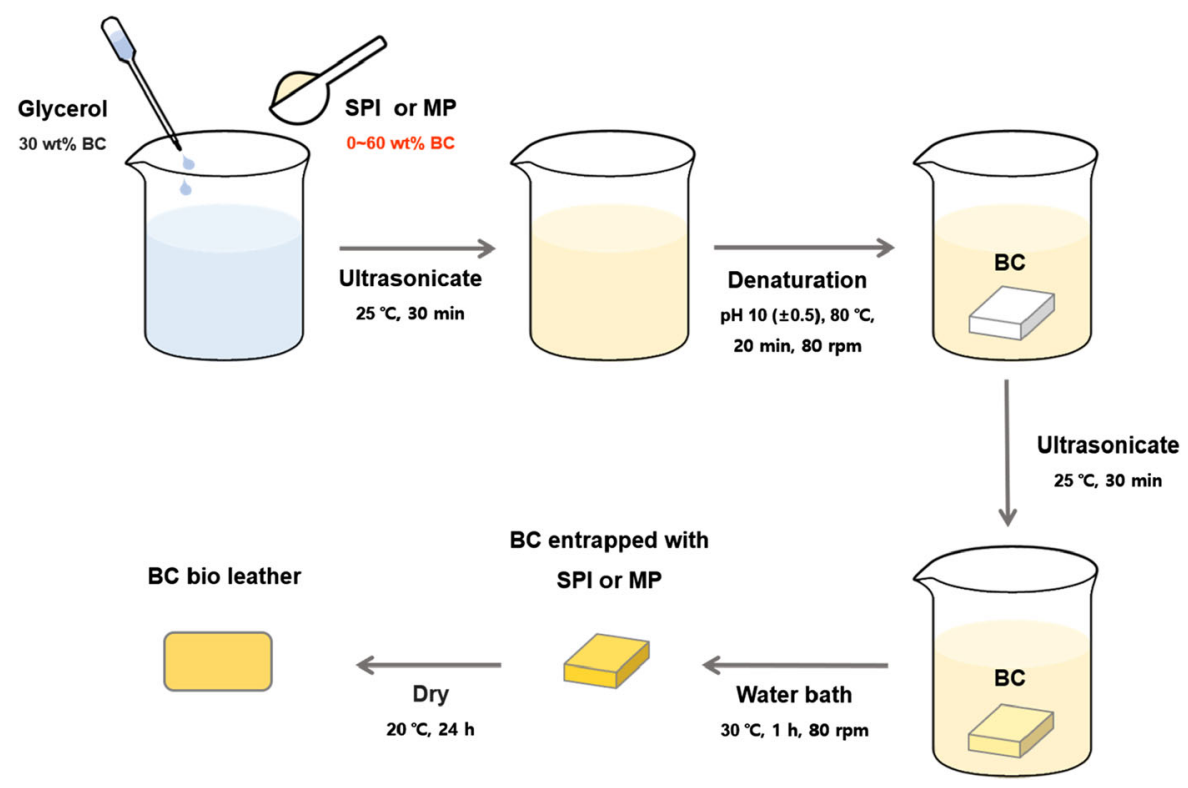

Fig. 1 Schematic illustration of the production method of BC bio-leathers 
TECH Co., Daejeon, Korea) at $80{ }^{\circ} \mathrm{C}$ for $20 \mathrm{~min}$ at $80 \mathrm{rpm}$. The pretreated $\mathrm{BC}$ bio-leather was then immersed in the solutions, ultrasonicated for $30 \mathrm{~min}$ at $25{ }^{\circ} \mathrm{C}$, and additionally treated at $30{ }^{\circ} \mathrm{C}$ in a shaking water bath for $1 \mathrm{~h}$ at $80 \mathrm{rpm}$. Finally, the obtained BC bio-leathers were dried in a drying oven $(\mathrm{OF}-22 \mathrm{G}$; JEIO TECH Co., Daejeon, Korea) for $24 \mathrm{~h}$ at $20^{\circ} \mathrm{C}$.

Evaluation of the durability of $\mathrm{BC}$ bio-leather

The durability of BC bio-leather before and after physical entrapment of proteins was tested by the evaluation of parameters such as water resistance, tensile strength, flexibility, crease recovery, and dimensional stability.

\section{Water resistance}

The water resistance properties were examined by water contact angle (WCA) and water absorption time measurements. First, WCA was analyzed using a contact angle measurement system (DSA 25; KRUSS Inc., Hamburg, Germany) by the sessile drop method, in which a $2 \mu \mathrm{L}$ droplet of deionized water was placed on the surface of each sample using a Hamilton $500 \mu \mathrm{L}$ syringe at a suitable distance to the testing platform. The angle formed by the tangent of the droplet with the surface of each sample was recorded by ADVANCE software (KRUSS Inc., Hamburg, Germany). The average WCA value was obtained by measuring five different spots on the surface of each sample. Next, the water absorption time measurement was performed according to Song et al. (2019). A $0.01 \%$ Methylene blue (C.I. 52,015) solution was used to visually confirm the complete absorption of droplets on the surface of samples. A $5 \mu \mathrm{L}$ drop of this solution was placed onto the surface of each sample, and the water absorption time was measured until the specular reflectance of a droplet was completely disappeared.

\section{Tensile strength}

The tensile strength was evaluated according to ISO 13934-2:2014 (Tensile properties of fabrics-Determination of maximum force using the grab method) with a slight modification in the size of the tested sample. The size of the sample was modified to $5 \times 10 \mathrm{~cm}$. All measurements were performed five times for each sample, and the average values were obtained.

\section{Flexibility}

The flexibility was tested according to ASTM D138818 (Standard Test Method for Stiffness of Fabrics: The Heart Loop Test) with some modifications. The size of the sample was modified to $5 \times 10 \mathrm{~cm}$. Samples were shaped as loops, and after $1 \mathrm{~min}$, the distance from the upper end to the lowest point of the loop was measured. The change in distance was calculated according to the following Eq. (2):

$\Delta d(\%)=\frac{d_{1}-d_{0}}{d_{0}} \times 100$

where $\Delta d$ is the change in the distance, $d_{0}$ is the distance of the loop before the measurement, and $d_{1}$ is the distance of the loop after $1 \mathrm{~min}$.

\section{Crease recovery}

The crease recovery angles were measured according to ISO 2313:1972 (Determination of the recovery from creasing of a horizontally folded specimen of fabric by measuring the angle of recovery). Crease recovery was calculated according to the following Eq. (3):

Crease recovery $(\%)=\frac{\text { crease recovery angle }\left({ }^{\circ}\right)}{}$

All measurements were performed five times for each sample and the results were averaged.

\section{Dimensional stability}

The dimensional stability was evaluated according to ISO 7771:1985 (Determination of dimensional changes of fabrics induced by cold-water immersion) with a slight modification. The size of the samples was modified to $5 \times 10 \mathrm{~cm}$, and the experiment time was varied from 60 to $180 \mathrm{~min}$. Samples were marked at four points to measure the dimensional change. Samples were immersed in $0.5 \mathrm{~g} / \mathrm{L}$ of a wetting agent (sodium dodecylbenzenesulfonate, $\mathrm{C}_{18} \mathrm{~N}_{29} \mathrm{NaO}_{3} \mathrm{~S}$ ). After immersion, BC bio-leathers were dried in a drying oven at $25^{\circ} \mathrm{C}$ for $5 \mathrm{~h}$, and then the dimensional 
change was measured. The percentage of dimensional stability was calculated using the following Eq. (4):

Dimensional stability $(\%)=\frac{A_{m m}}{B_{m m}} \times 100$

where $B_{m m}$ is the size in millimeters of samples before immersion, and $A_{m m}$ is the size in millimeters of samples after immersion. All samples were tested five times and the average value was measured.

Surface analysis of BC bio-leathers

A Fourier transform-infrared (FT-IR) spectrometer (Nicolet IS50; Thermo Fisher Scientific, MA, USA) was used to examine the chemical structures of BC bio-leathers. The FT-IR spectra of the samples were recorded in the wavenumber range of $650-4000 \mathrm{~cm}^{-1}$ at a resolution of $0.4 \mathrm{~cm}^{-1}$ with 32 scans. Baseline normalization was carried out for each spectrum using OMNIC software (Thermo Fisher Scientific, MA, USA).

The crystalline structures of BC bio-leathers were examined by X-ray diffraction (XRD) analysis using a D8 ADVANCE diffractometer (Bruker AXS Inc., WI, USA) in the $2 \theta$ range of $0^{\circ}-40^{\circ}$. XRD measurements were carried out with a $\mathrm{Cu}-\mathrm{K}_{\alpha}$ radiation source $(\lambda=1.5406 \mathrm{~nm})$ at $40 \mathrm{kV}$ and $40 \mathrm{~mA}$.

The surface morphologies of $\mathrm{BC}$ bio-leathers were characterized by a field emission scanning electron microscope (FE-SEM) (JSM-7600F; JEOL Ltd., Tokyo, Japan). All samples were sputter-coated with platinum using a magnetron sputter coater (108auto; Cressington Scientific Instruments, Watford, UK) and then observed at an acceleration voltage of $3 \mathrm{kV}$.

Along with the SEM analysis using FE-SEM, energy dispersive X-ray analysis (EDX) was performed to determine the existence of plant-based proteins inside BC bio-leathers. All samples were sputter-coated with platinum using a magnetron sputter coater (108auto; Cressington Scientific Instruments, Watford, UK).

\section{Results and discussion}

Physical entrapment of plant-based proteins on $\mathrm{BC}$ bio-leather

The physical entrapment of plant-based proteins on $\mathrm{BC}$ bio-leather was controlled by evaluating the amount of proteins from 0 to $60 \mathrm{wt} \%$ of $\mathrm{BC}$. The amount of protein to be entrapped was determined by selecting the production conditions with the highest tensile strength. The conditions used in determining the amounts of SPI and MP, and tensile strength (N) with standard deviations were presented in Table 1. As shown in Fig. 2a, b, the tensile strength of $\mathrm{BC}$ bio-leather increased with an increase in the amount of entrapped proteins. In Fig. 2a, after entrapping SPI at an amount of $20 \mathrm{wt} \%$ of $\mathrm{BC}$, the tensile strength of $\mathrm{BC}$ bio-leather increased approximately 3.73 times compared to that of the original BC. When the amount of SPI exceeded $20 \mathrm{wt} \%$ of BC, there was no significant change in the tensile strength of $\mathrm{BC}$ bio-leather, which is attributed to the lower availability of bonding sites in $\mathrm{BC}$ to react with functional groups of SPI (Behera et al. 2012). In Fig. $2 b$, the highest tensile strength value was obtained when MP at an amount of $50 \mathrm{wt} \%$ of BC was entrapped. However, the tensile strength of $\mathrm{BC}$ bio-leather decreased after entrapping $\mathrm{MP}$ at an amount of $60 \mathrm{wt} \%$ of BC. This may have occurred because there were fewer available hydroxyl groups in $\mathrm{BC}$ to react with functional groups of MP. Hence, the excess MP molecules agglomerated on the surface of $\mathrm{BC}$ bio-leather, disrupting the interaction between $\mathrm{BC}$ and MP (Xie et al. 2020).

The reason why the optimum amount of SPI and MP are different is that the amino acid composition, which can react with hydroxyl groups in BC (Liu et al. 2017), are different. Thus, the reactivity of SPI and MP with BC would be different. To be specific, SPI is composed of amino acids such as lysine, arginine, histidine, glutamate, aspartate, serine, threonine, and tyrosine (Liu et al. 2017), and MP is consisted of amino acids such as serine, threonine, alanine, proline, aspartic acid, glutamic acid, leucine, isoleucine, lysine, methionine, phenylalanine, and histidine (Finimundy et al. 2014; Park et al. 2017). We assumed that the differences in the amino acid compositions of SPI and MP had an influence on the tensile strength of BC bio-leathers, but we could not specify which element 
Table 1 Conditions used in determining the amounts of SPI and MP, and tensile strength (N) with standard deviations

\begin{tabular}{llllc}
\hline Sample \# & Protein & Amount $(w t \%$ BC) & Glycerol (wt\% BC) & Tensile strength (N) \\
\hline 1 & - & - & 30 & $63.6 \pm 8.3$ \\
2 & SPI & 10 & 30 & $425.3 \pm 96.9$ \\
3 & SPI & 20 & 30 & $589.1 \pm 54.9$ \\
4 & SPI & 30 & 30 & $583.9 \pm 66.2$ \\
5 & SPI & 40 & 30 & $542.5 \pm 53.5$ \\
6 & SPI & 50 & 30 & $569.5 \pm 40.7$ \\
7 & SPI & 60 & 30 & $536.3 \pm 32.2$ \\
8 & MP & 10 & 30 & $308.2 \pm 158.7$ \\
9 & MP & 20 & 30 & $307.4 \pm 153.7$ \\
10 & MP & 30 & 30 & $430.7 \pm 150.6$ \\
11 & MP & 40 & 30 & $531.5 \pm 46.4$ \\
12 & MP & 50 & 30 & $647.3 \pm 27.0$ \\
13 & MP & 60 & 30 & $462.6 \pm 209.0$ \\
\hline
\end{tabular}

(a)

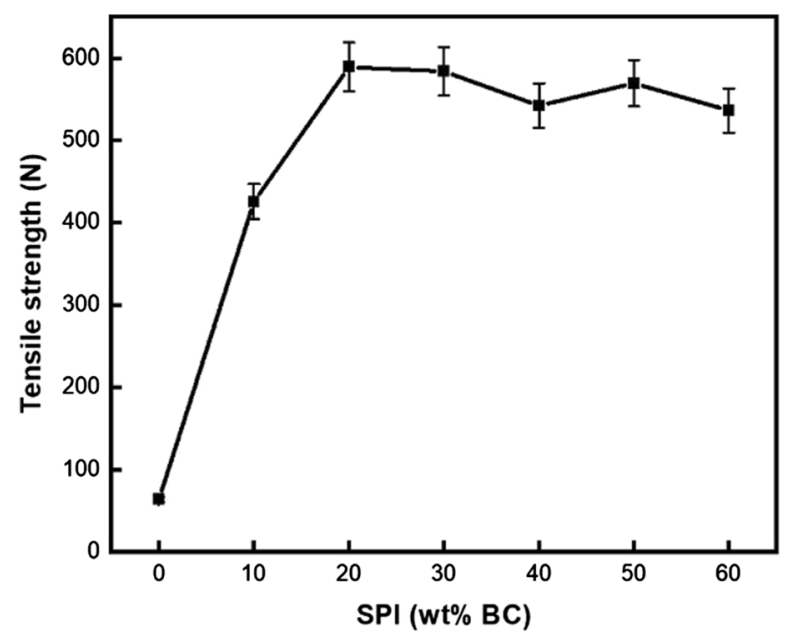

(b)

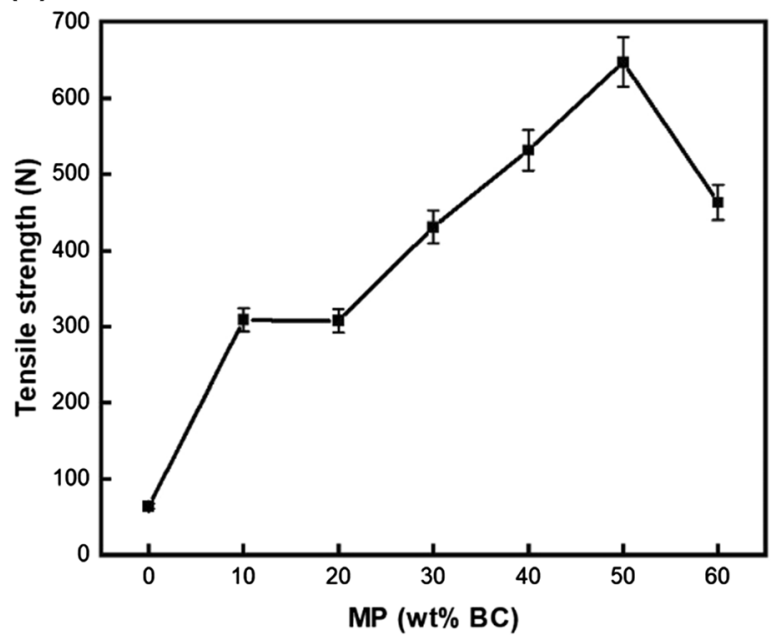

Fig. 2 The change in tensile strength (N) of different amounts of a SPI and b MP entrapped in BC with $95 \%$ confidence interval bars

had improved the tensile strength. However, this study is mainly focused on the methods of improving the durability of $\mathrm{BC}$ to be used as a leather substitute. Thus, we found that when physically entrapping proteins inside $\mathrm{BC}$, the amount of proteins had to be controlled due to the different amino acid composition of each protein.

Evaluation of the durability of BC bio-leather

To confirm the effect of only proteins in the durability of BC bio-leathers, samples entrapped with only SPI or MP and a sample entrapped with only glycerol were produced and analyzed. Samples were coded as follows. BC samples entrapped with both proteins and glycerol were named as BC-SPI (with glycerol) and BC-MP (with glycerol), respectively. BC samples entrapped with proteins only were named as BC-SPI (without glycerol) and BC-MP (without glycerol), respectively. In the case of $\mathrm{BC}$ entrapped with only glycerol, the sample was named as BC-glycerol.

Before the evaluation, the thickness and weight of each sample was measured ten times and the average values were provided in Table 2. 
Table 2 Fabric characterizations of original BC, cowhide leather, BC-glycerol, BC-SPI (with glycerol), BC-SPI (without glycerol), BC-MP (with glycerol), and BC-MP (without glycerol) (production conditions for BC-SPI (with glycerol): fabric to liquor ratio of 1:10, SPI at an amount of $20 \mathrm{wt} \%$ of $\mathrm{BC}$, $30 \mathrm{wt} \%$ of BC of glycerol; production conditions for BC-SPI (without glycerol): fabric to liquor ratio of $1: 10$, SPI at an amount of $20 \mathrm{wt} \%$ of $\mathrm{BC}$; production conditions for BC-MP (with glycerol): fabric to liquor ratio of 1:10, MP at an amount of $50 \mathrm{wt} \%$ of $\mathrm{BC}, 30 \mathrm{wt} \%$ of $\mathrm{BC}$ of glycerol; production conditions for $\mathrm{BC}-\mathrm{MP}$ (without glycerol): fabric to liquor ratio of $1: 10, \mathrm{MP}$ at an amount of $50 \mathrm{wt} \%$ of BC)

\begin{tabular}{lll}
\hline Sample & Thickness $(\mathrm{mm})$ & Weight $\left(\mathrm{g} / \mathrm{m}^{2}\right)$ \\
\hline Original BC & $0.9 \pm 0.1$ & $186.7 \pm 12.5$ \\
Cowhide leather & $0.7 \pm 0.1$ & $466.7 \pm 18.3$ \\
BC-glycerol & $0.5 \pm 0.2$ & $190.0 \pm 37.2$ \\
BC-SPI (with glycerol) & $0.7 \pm 0.2$ & $466.0 \pm 34.5$ \\
BC-SPI (without glycerol) & $0.5 \pm 0.1$ & $104.0 \pm 25.3$ \\
BC-MP (with glycerol) & $0.5 \pm 0.1$ & $364.0 \pm 32.8$ \\
BC-MP (without glycerol) & $0.5 \pm 0.1$ & $173.3 \pm 19.0$ \\
\hline
\end{tabular}

\section{Water resistance}

The water resistance of $\mathrm{BC}$ bio-leather was measured by WCA and the water absorption time. As shown in Fig. 3, the original $\mathrm{BC}$ had the lowest WCA. This is due to the free hydroxyl groups in BC, which exhibit hydrophilic properties (Wen et al. 2015). BC-glycerol also had a low WCA, which was related to the hydrophilic behavior of glycerol (Epure et al. 2011). After physical entrapment of plant-based proteins inside BC, WCAs were increased significantly. The increased WCAs could be attributed to the formation of hydrogen bonding between BC fibers and plantbased proteins, reducing the number of free hydroxyl groups, and thus increasing the hydrophobicity of BC bio-leather (Lima et al. 2018). It was also found that BC entrapped with both protein and glycerol had improved WCA than BC entrapped with protein only. This could be explained by the rearrangement of hydrophobic moieties of protein molecules: Glycerol may strengthen the interactions with protein molecules by forming hydrogen bonds, resulting in the reorientation of hydrophobic moieties of proteins on the surface of BC bio-leathers (Yin et al. 2007). Moreover, both BC-SPI (with glycerol) and BC-MP (with glycerol) were found to have better WCAs when

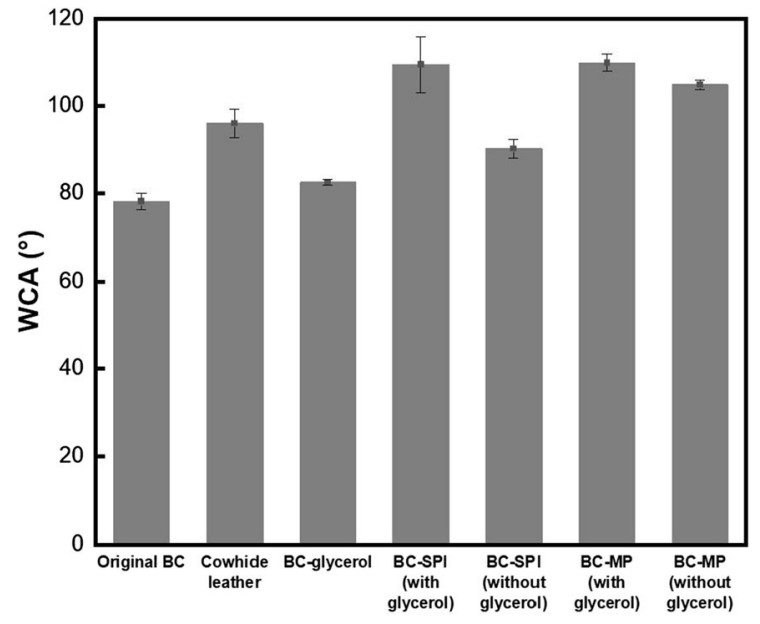

Fig. 3 Average WCA of original BC, cowhide leather, BCglycerol, BC-SPI (with glycerol), BC-SPI (without glycerol), $\mathrm{BC}-\mathrm{MP}$ (with glycerol), and BC-MP (without glycerol) (production conditions for BC-SPI (with glycerol): fabric to liquor ratio of 1:10, SPI at an amount of $20 \mathrm{wt} \%$ of BC, $30 \mathrm{wt} \%$ of BC of glycerol; production conditions for BC-SPI (without glycerol): fabric to liquor ratio of $1: 10$, SPI at an amount of $20 \mathrm{wt} \%$ of $\mathrm{BC}$; production conditions for BC-MP (with glycerol): fabric to liquor ratio of $1: 10, \mathrm{MP}$ at an amount of $50 \mathrm{wt} \%$ of $\mathrm{BC}$, $30 \mathrm{wt} \%$ of BC of glycerol; production conditions for BC-MP (without glycerol): fabric to liquor ratio of $1: 10, \mathrm{MP}$ at an amount of $50 \mathrm{wt} \%$ of BC)

glycerol was added. Those WCAs were higher than cowhide leather of similar thickness.

Figure 4 describes the water absorption behaviors of $\mathrm{BC}$ bio-leather. When the water droplet was dropped on the surface of the original BC, it quickly spread sideways and was completely absorbed within 10 min. Since BC has high water retention capability and hydrophilicity ( $\mathrm{Li}$ et al. 2014), BC can absorb water quickly. BC-glycerol also absorbed the water droplet completely within $10 \mathrm{~min}$ due to the water sensitivity and hydrophilicity of glycerol (Tian et al. 2018). After BC was entrapped with plant-based proteins such as SPI and MP, the water absorption time of BC was increased. Moreover, it took a longer time for BC entrapped with both proteins and glycerol, compared to $\mathrm{BC}$ entrapped with only proteins. This phenomenon was in accordance with the WCA result, which could be attributed to the reorientation of hydrophobic functional groups of proteins on the surface of BC by the addition of glycerol (Yin et al. 2007).

Based on these results, it was confirmed that the water resistance of $\mathrm{BC}$ bio-leather could be improved 


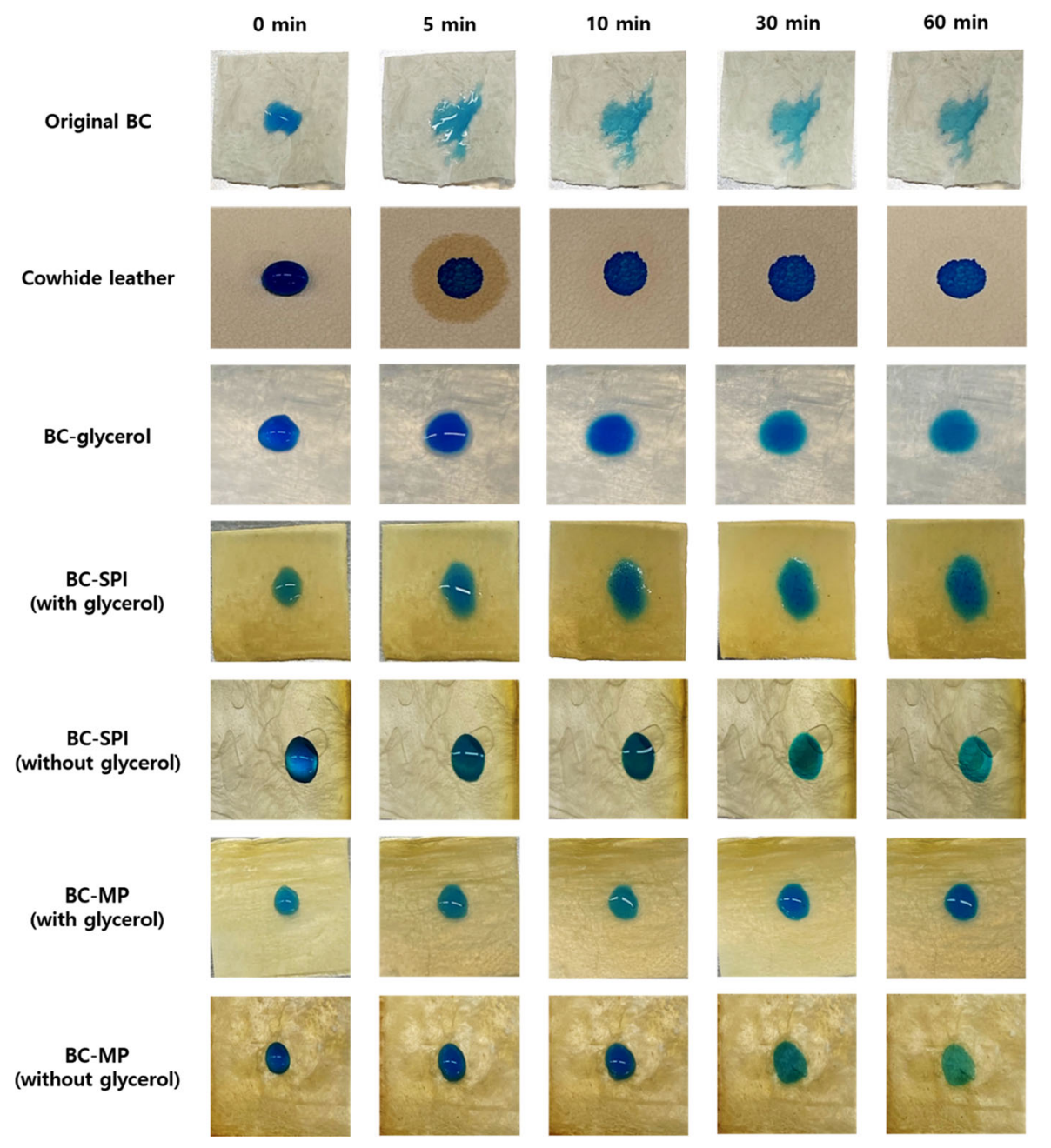

Fig. 4 Water absorption behaviors of original $\mathrm{BC}$, cowhide leather, BC-glycerol, BC-SPI (with glycerol), BC-SPI (without glycerol), BC-MP (with glycerol), and BC-MP (without glycerol) (production conditions for BC-SPI (with glycerol): fabric to liquor ratio of 1:10, SPI at an amount of $20 \mathrm{wt} \%$ of BC, $30 \mathrm{wt} \%$ of $\mathrm{BC}$ of glycerol; production conditions for BC-SPI

by entrapping proteins such as SPI and MP, and that BC-SPI (with glycerol) and BC-MP (with glycerol) had better water resistance compared to cowhide leather of similar thickness.

\section{Tensile strength}

The tensile strength of $\mathrm{BC}$ bio-leather was tested after physical entrapment of SPI and MP. In Fig. 5, the original $\mathrm{BC}$ had poor tensile strength due to the brittle property of BC (Feng et al. 2012; Muller et al. 2013). BC entrapped with only SPI had the lowest tensile

(without glycerol): fabric to liquor ratio of $1: 10$, SPI at an amount of $20 \mathrm{wt} \%$ of $\mathrm{BC}$; production conditions for BC-MP (with glycerol): fabric to liquor ratio of $1: 10, \mathrm{MP}$ at an amount of $50 \mathrm{wt} \%$ of $\mathrm{BC}, 30 \mathrm{wt} \%$ of $\mathrm{BC}$ of glycerol; production conditions for BC-MP (without glycerol): fabric to liquor ratio of 1:10, MP at an amount of $50 \mathrm{wt} \%$ of BC)

strength because of the stiff and brittle nature of SPI (Kokoszka et al. 2010). After the physical entrapment of proteins with glycerol, the tensile strength of BC remarkably increased. It is explained that the addition of glycerol improved the processability of plant-based proteins, and thus proteins could be effectively entrapped in BC (Wang et al. 2017; Tian et al. 2018). Moreover, BC-MP (with glycerol) had better tensile strength than cowhide leather of similar thickness. These results showed that the mechanical properties of BC were successfully enhanced by physical entrapment of plant-based proteins, and that 


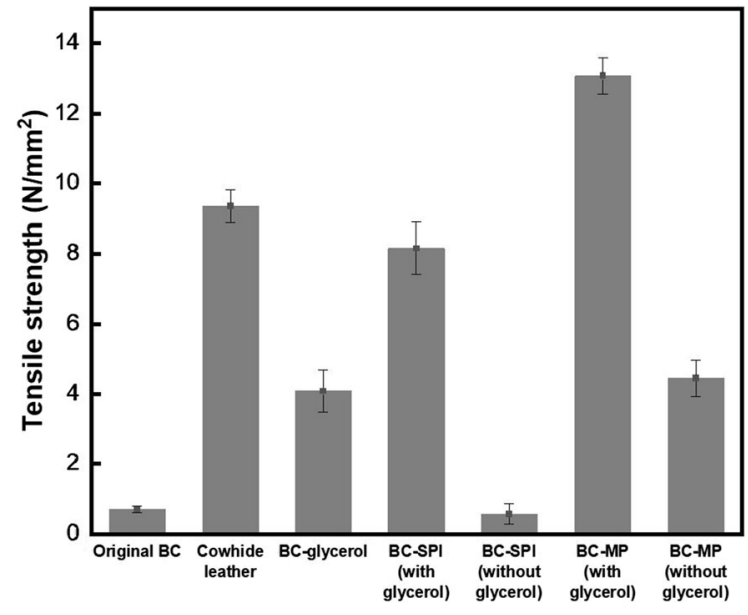

Fig. 5 Tensile strength of original $\mathrm{BC}$, cowhide leather, $\mathrm{BC}$ glycerol, BC-SPI (with glycerol), BC-SPI (without glycerol), BC-MP (with glycerol), and BC-MP (without glycerol) (production conditions for BC-SPI (with glycerol): fabric to liquor ratio of 1:10, SPI at an amount of $20 \mathrm{wt} \%$ of BC, $30 \mathrm{wt} \%$ of BC of glycerol; production conditions for BC-SPI (without glycerol): fabric to liquor ratio of $1: 10$, SPI at an amount of $20 \mathrm{wt} \%$ of $\mathrm{BC}$; production conditions for BC-MP (with glycerol): fabric to liquor ratio of $1: 10, \mathrm{MP}$ at an amount of $50 \mathrm{wt} \%$ of $\mathrm{BC}$, $30 \mathrm{wt} \%$ of BC of glycerol; production conditions for BC-MP (without glycerol): fabric to liquor ratio of $1: 10$, MP at an amount of $50 \mathrm{wt} \%$ of BC)

glycerol was essential to control the processability of proteins.

\section{Flexibility}

The flexibility test results of $\mathrm{BC}$ bio-leather according to the modified heart-loop method are shown in Figs. 6 and $7 \mathrm{a}$. When the sample shows better flexibility, the change in the distance between the upper and lower ends of the loop increases (Abbott 1951). BC-glycerol had the highest change in the distance of the loop among all samples. This is because glycerol itself could act as a plasticizer that improves the flexibility of BC (Cielecka et al. 2019). The original BC had some cracks when it was bent into a loop, and it had very low change in the distance of the loop. This might be due to the stiff and brittle nature of BC (Feng et al. 2012; Muller et al. 2013). When BC entrapped with SPI only, it was impossible to measure the flexibility of BC. This could be explained that the strong polar interactions between SPI molecules and hydroxyl groups of BC decreased molecular mobility, resulting in the increased brittleness of BC (Kokoszka et al.
2010). Meanwhile, BC entrapped with MP only was found to have a certain level of flexibility even in the absence of glycerol because some fungal biomass included in MP might have influenced the flexibility of BC (Silverman 2018). When BC was entrapped with both proteins and glycerol, the flexibility was improved. This is consistent with the previous studies that glycerol was needed to improve the processability of proteins by reducing the intermolecular forces between protein chains (Kokoszka et al. 2010; Tian et al. 2012; Chhavi et al. 2017; Rhim et al. 2006). Moreover, the flexibility of BC-SPI (with glycerol) and BC-MP (with glycerol) was improved than that of cowhide leather of similar thickness by the addition of glycerol. Thus, it was confirmed that the flexibility of BC could be improved by entrapping both proteins and glycerol, and MP itself can impart the flexibility to BC.

\section{Crease recovery}

Generally, a sample with good crease recovery can return to its original state without being damaged (Kim et al. 2020a). Thus, it can be assumed that a sample with a high crease recovery value has good durability (Kim et al. 2020a). According to Fig. 7b, the crease recovery of original $\mathrm{BC}$ was $27.8 \%$. After the entrapment of SPI only, the crease recovery of BC bio-leather could not be measured because the sample was broken due to the highly brittle property (Kokoszka et al. 2010). After entrapping both plantbased proteins and glycerol, the crease recovery of BC bio-leather was highly improved. This could be explained that glycerol improved the processability of proteins by weakening the intermolecular forces between protein chains (Chhavi et al. 2017; Rhim et al. 2006). However, entrapping glycerol itself could not improve the crease recovery of $\mathrm{BC}$. Although the flexibility of BC-glycerol was good due to the reduced rigidity of BC (Indrarti et al. 2016; Cielecka et al. 2019), the crease recovery of BC-glycerol was poor than the original $\mathrm{BC}$ because the sample was too soft to retain its shape. In addition, the highest value of crease recovery was observed for BC-MP (with glycerol), showing that it has the best ability to return to its original shape among other samples. From the crease recovery analysis, it was confirmed that glycerol is essential to improve the processability of plant-based proteins, and that it was difficult to produce $\mathrm{BC}$ bio- 


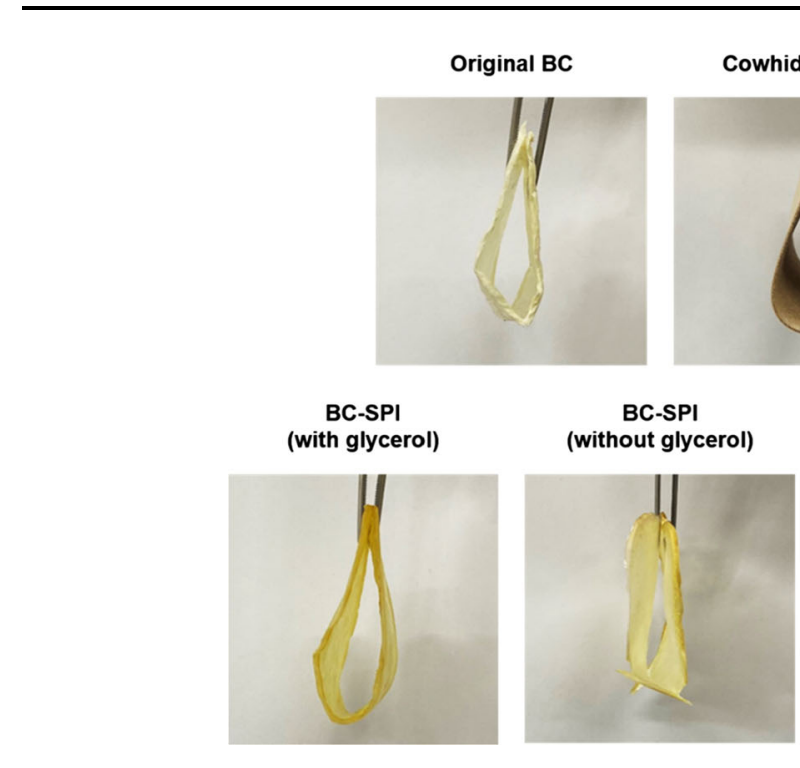

Fig. 6 The appearance of loops of original BC, cowhide leather, BC-glycerol, BC-SPI (with glycerol), BC-SPI (without glycerol), BC-MP (with glycerol), and BC-MP (without glycerol) (production conditions for BC-SPI (with glycerol): fabric to liquor ratio of 1:10, SPI at an amount of $20 \mathrm{wt} \%$ of BC, $30 \mathrm{wt} \%$ of $\mathrm{BC}$ of glycerol; production conditions for BC-SPI

(a)

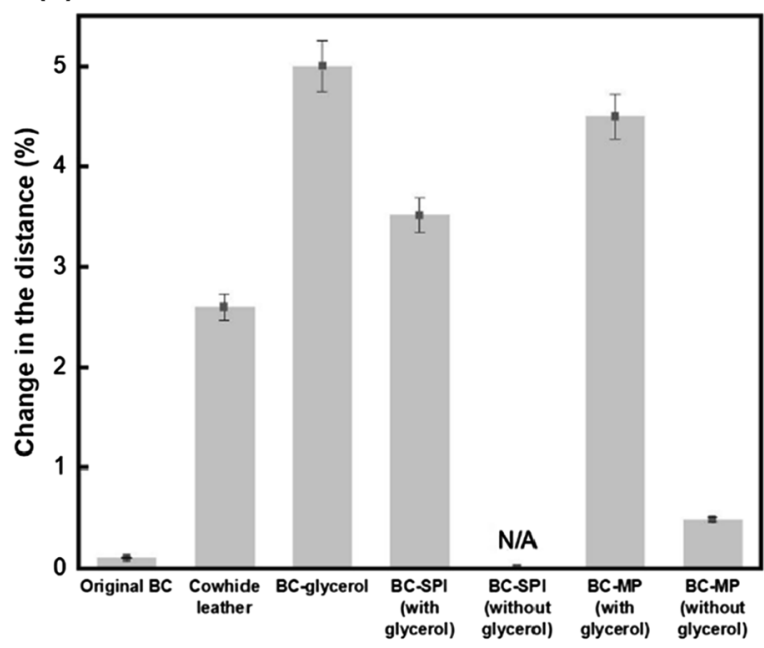

Fig. 7 a The change in the distance of loops (\%); b the crease recovery $(\%)$ of original $\mathrm{BC}$, cowhide leather, $\mathrm{BC}$-glycerol, $\mathrm{BC}$ SPI (with glycerol), BC-SPI (without glycerol), BC-MP (with glycerol), and BC-MP (without glycerol) (production conditions for BC-SPI (with glycerol): fabric to liquor ratio of 1:10, SPI at an amount of $20 \mathrm{wt} \%$ of BC, $30 \mathrm{wt} \%$ of BC of glycerol; production conditions for BC-SPI (without glycerol): fabric to
BC-glycerol
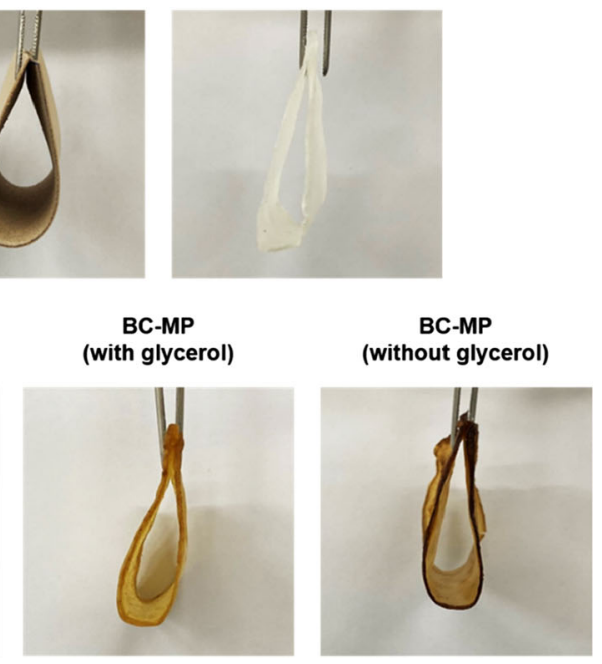

(without glycerol): fabric to liquor ratio of $1: 10$, SPI at an amount of $20 \mathrm{wt} \%$ of $\mathrm{BC}$; production conditions for BC-MP (with glycerol): fabric to liquor ratio of $1: 10, \mathrm{MP}$ at an amount of $50 \mathrm{wt} \%$ of $\mathrm{BC}, 30 \mathrm{wt} \%$ of $\mathrm{BC}$ of glycerol; production conditions for BC-MP (without glycerol): fabric to liquor ratio of 1:10, MP at an amount of $50 \mathrm{wt} \%$ of BC)

(b)

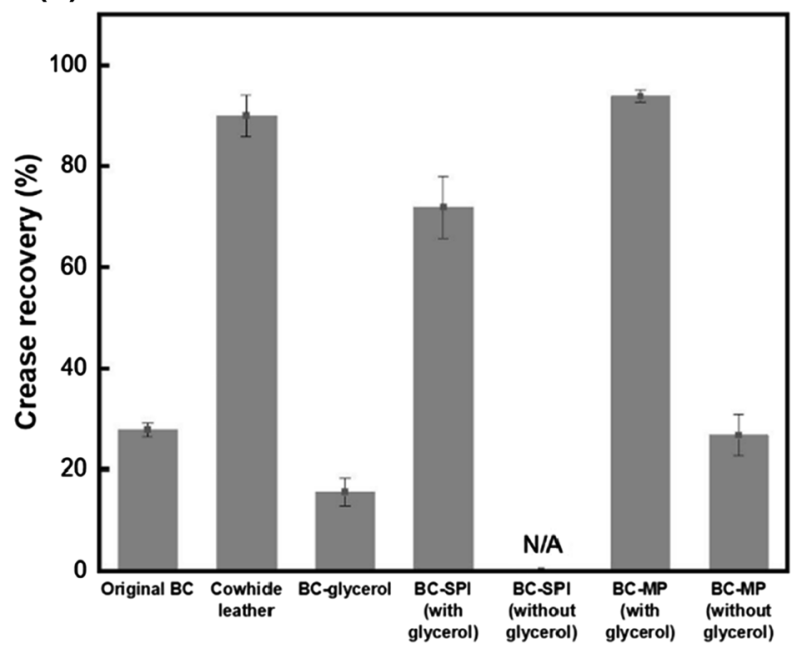

liquor ratio of $1: 10$, SPI at an amount of $20 \mathrm{wt} \%$ of $\mathrm{BC}$; production conditions for $\mathrm{BC}-\mathrm{MP}$ (with glycerol): fabric to liquor ratio of 1:10, MP at an amount of $50 \mathrm{wt} \%$ of BC, $30 \mathrm{wt} \%$ of BC of glycerol; production conditions for BC-MP (without glycerol): fabric to liquor ratio of $1: 10, \mathrm{MP}$ at an amount of $50 \mathrm{wt} \%$ of $\mathrm{BC}$ ) 


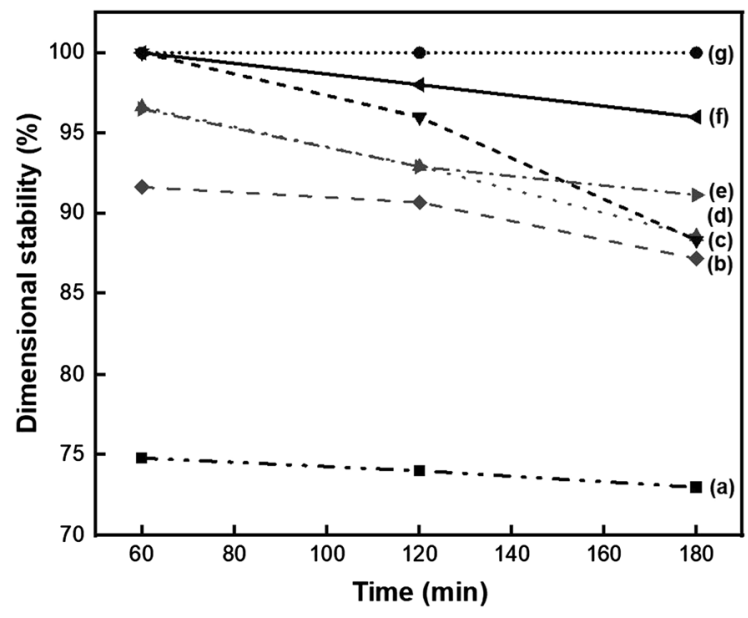

Fig. 8 The dimensional stability (\%) of a original BC, b BCSPI (without glycerol), c BC-SPI (with glycerol), d BCglycerol, e BC-MP (without glycerol), f BC-MP (with glycerol), and $\mathbf{g}$ cowhide leather (production conditions for BC-SPI (with glycerol): fabric to liquor ratio of 1:10, SPI at an amount of $20 \mathrm{wt} \%$ of $\mathrm{BC}, 30 \mathrm{wt} \%$ of $\mathrm{BC}$ of glycerol; production conditions for BC-SPI (without glycerol): fabric to liquor ratio of $1: 10$, SPI at an amount of $20 \mathrm{wt} \%$ of $\mathrm{BC}$; production conditions for BC-MP (with glycerol): fabric to liquor ratio of $1: 10, \mathrm{MP}$ at an amount of $50 \mathrm{wt} \%$ of $\mathrm{BC}, 30 \mathrm{wt} \%$ of $\mathrm{BC}$ of glycerol; production conditions for BC-MP (without glycerol): fabric to liquor ratio of $1: 10, \mathrm{MP}$ at an amount of $50 \mathrm{wt} \%$ of BC)

leather with good crease recovery by entrapping proteins only.

\section{Dimensional stability}

Figure 8 demonstrates the dimensional stability of $\mathrm{BC}$ bio-leather. In Fig. 8a, the dimensional stability of the original $\mathrm{BC}$ decreased from 74.5 to $73.0 \%$ after immersion in the wetting solution for $180 \mathrm{~min}$. BC shrank remarkably after drying due to the high water absorption property of $\mathrm{BC}$ ( $\mathrm{Li}$ et al. 2014). After entrapping SPI and MP only, the dimensional stability of $\mathrm{BC}$ was improved about $20 \%$ and $31 \%$, respectively. By the addition of glycerol, the dimensional stability of BC-SPI (with glycerol) (Fig. 8c) and BCMP (with glycerol) (Fig. 8f) was further increased. This could be due to the strong adhesion between $\mathrm{BC}$ nanofibers and proteins which decreased the water absorption, as evidenced in the water resistance analysis (Song et al. 2019), and the enhanced processability of proteins by the addition of glycerol (Wang et al. 2017). On the other hand, entrapping glycerol only was not sufficient to improve the dimensional stability of BC (Fig. 8d). As confirmed in the water resistance analysis (Fig. 3), glycerol is a hydrophilic material so that it absorbs the wetting agent well, resulting in a low dimensional stability. Moreover, the dimensional stability of BC-MP (with glycerol) was comparable to that of cowhide leather (Fig. 8g), confirming that BC-MP (with glycerol) could be a suitable leather substitute.

Surface analyses of BC bio-leathers

After evaluating the physical properties of BC bioleather by comparison with cowhide leather, it was confirmed that the durability of BC bio-leather could be improved by physical entrapment of both proteins and glycerol. Thus, the surface analyses, such as FTIR, XRD, SEM, and EDX, were performed with original BC, BC-SPI (with glycerol), and BC-MP (with glycerol). Here in, BC-SPI (with glycerol) and BC-MP (with glycerol) were coded as BC-SPI $(G)$ and $\mathrm{BC}-\mathrm{MP}(\mathrm{G})$, respectively.

FT-IR was used to evaluate the physically entrapped plant-based proteins inside BC bio-leathers. As indicated in Fig. 9, all FT-IR spectra displayed peaks around $3350 \mathrm{~cm}^{-1}$ to $3400 \mathrm{~cm}^{-1}$, and around $2900 \mathrm{~cm}^{-1}$, indicating the presence of hydrogenbonded $-\mathrm{OH}$ groups of cellulose and the presence of amorphous cellulose, respectively ( Fu and Liu 2011; Vigentini et al. 2019) (Table 3). These peaks confirmed that the chemical structure of BC remained unchanged after entrapping proteins such as SPI and MP. In addition, the FT-IR spectrum of proteins usually has nine characteristic absorption bands, among which amide $\mathrm{I}\left(\sim 1650 \mathrm{~cm}^{-1}\right)$ and amide II $\left(\sim 1550 \mathrm{~cm}^{-1}\right)$ bands are the two major bands (Qi et al. 2016; Yang et al. 2015; Gu et al. 2019). In the FTIR spectra of BC-SPI $(\mathrm{G})$ and $\mathrm{BC}-\mathrm{MP}(\mathrm{G})$, amide I and amide II peaks were clearly observed. These peaks were ascribed to the presence of SPI and MP inside $\mathrm{BC}-\mathrm{SPI}(\mathrm{G})$ and $\mathrm{BC}-\mathrm{MP}(\mathrm{G})$, respectively.

$\mathrm{XRD}$ was used to examine the crystalline structures of BC bio-leathers. In Fig. 10, three peaks at $2 \theta=14.5^{\circ}, 16.8^{\circ}$, and $22.7^{\circ}$ were observed in the diffraction patterns of original BC, BC-SPI(G), and BC-MP $(G)$, respectively. These peaks were attributed to the cellulose structure of BC (Bekatorou et al. 2019), implying that it was retained after the entrapment of SPI or MP. This was consistent with the FT-IR results discussed previously. In the XRD patterns of 


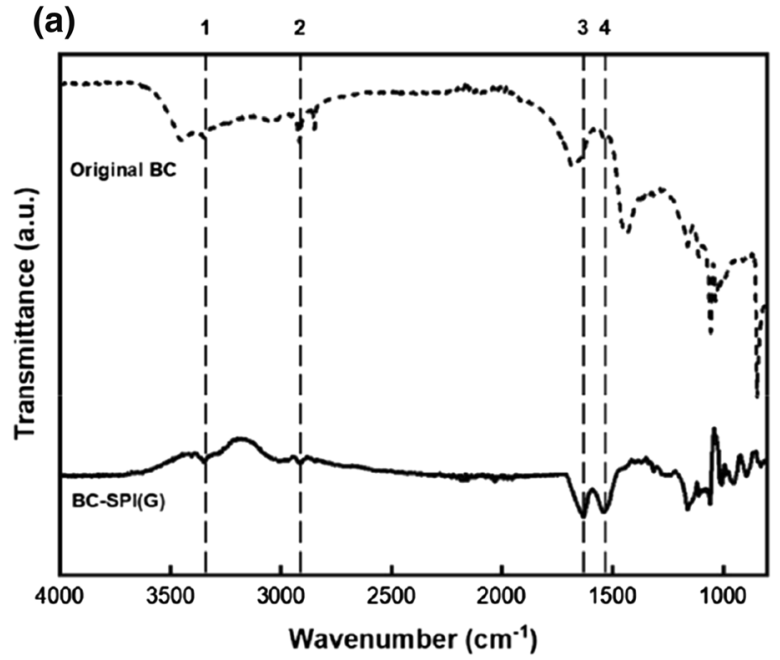

Fig. 9 FT-IR spectra of a original $\mathrm{BC}$ and $\mathrm{BC}-\mathrm{SPI}(\mathrm{G})$; b original $\mathrm{BC}$ and $\mathrm{BC}-\mathrm{MP}(\mathrm{G})$ (production conditions for $\mathrm{BC}$ $\mathrm{SPI}(\mathrm{G})$ : fabric to liquor ratio of $1: 10$, SPI at an amount of

Table 3 Characteristic peaks of original BC, BC-SPI $(\mathrm{G})$, and $\mathrm{BC}-\mathrm{MP}(\mathrm{G})$ (production conditions for $\mathrm{BC}-\mathrm{SPI}(\mathrm{G})$ : fabric to liquor ratio of $1: 10$, SPI at an amount of $20 \mathrm{wt} \%$ of $\mathrm{BC}$,

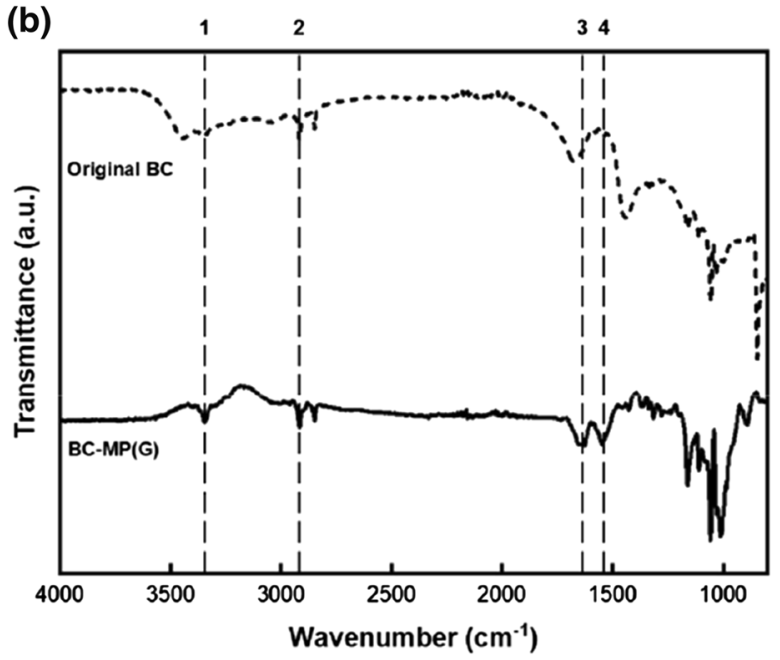

$20 \mathrm{wt} \%$ of $\mathrm{BC}, 30 \mathrm{wt} \%$ of $\mathrm{BC}$ of glycerol; production conditions for $\mathrm{BC}-\mathrm{MP}(\mathrm{G})$ : fabric to liquor ratio of 1:10, MP at an amount of $50 \mathrm{wt} \%$ of BC, $30 \mathrm{wt} \%$ of BC of glycerol)

$30 \mathrm{wt} \%$ of $\mathrm{BC}$ of glycerol; production conditions for BC$\mathrm{MP}(\mathrm{G})$ : fabric to liquor ratio of $1: 10, \mathrm{MP}$ at an amount of $50 \mathrm{wt} \%$ of BC, $30 \mathrm{wt} \%$ of $\mathrm{BC}$ of glycerol)

\begin{tabular}{lllll}
\hline \multicolumn{2}{l}{ Wavenumber $\left(\mathrm{cm}^{-1}\right)$} & & Peak assignment \\
\hline Peak no. & Original BC & BC-SPI(G) & BC-MP(G) & \\
\hline 1 & 3448 & 3350 & 3346 & -OH stretching (Fu and Liu 2011; Vigentini et al. 2019) \\
2 & 2916 & 3010 & 2915 & C-H stretching (Vigentini et al. 2019) \\
3 & - & 1630 & 1627 & C=O stretching (Qi et al. 2016; Yang et al. 2015) \\
4 & - & 1543 & 1548 & N-H bending (Yang et al. 2015; Gu et al. 2019) \\
\hline
\end{tabular}

SPI and MP powders, two characteristic peaks at $2 \theta=9.1^{\circ}$ and $20.2^{\circ}$, were observed. These peaks corresponded to the $\alpha$-helix and $\beta$-sheet structures of the protein secondary conformations, respectively (Pang et al. 2019). These peaks were also observed in the XRD patterns of BC-SPI $(\mathrm{G})$ and BC-MP(G), thus confirming the successful entrapment of proteins inside the $\mathrm{BC}$ nanostructure.

Table 4 shows the crystallinity degrees of $\mathrm{BC}$ bioleathers. In comparison with the original $\mathrm{BC}$, the crystallinity degrees of BC-SPI $(G)$ and BC-MP(G) decreased because protein chains could not move freely after being cross-linked with $\mathrm{BC}$ fibers $(\mathrm{Wu}$ et al. 2018). In most cases, when the crystallinity degree decreases, the tensile strength also decreases. However, the experimental results in this study showed the opposite tendency. According to Liu et al. (2013), the reason of this opposite tendency is that crystallinity is not a major factor that affects the tensile strength. It is known that the tensile strength of BC is more affected by the drying condition than crystallinity. Thus, factors other than the crystallinity might influence the improvement of the tensile strength of BC bioleather. Also, the decrease in the crystallinity could prove the successful cross-linking between BC fibers and protein chains.

The surface morphologies of $\mathrm{BC}$ bio-leathers are shown in Fig. 11. The SEM image of the original BC showed the fine cellulose nanostructure of BC. Different morphologies were observed after the entrapment of SPI and MP. In the SEM image of BC-SPI $(G)$, the SPI particles agglomerated inside the 
(a)

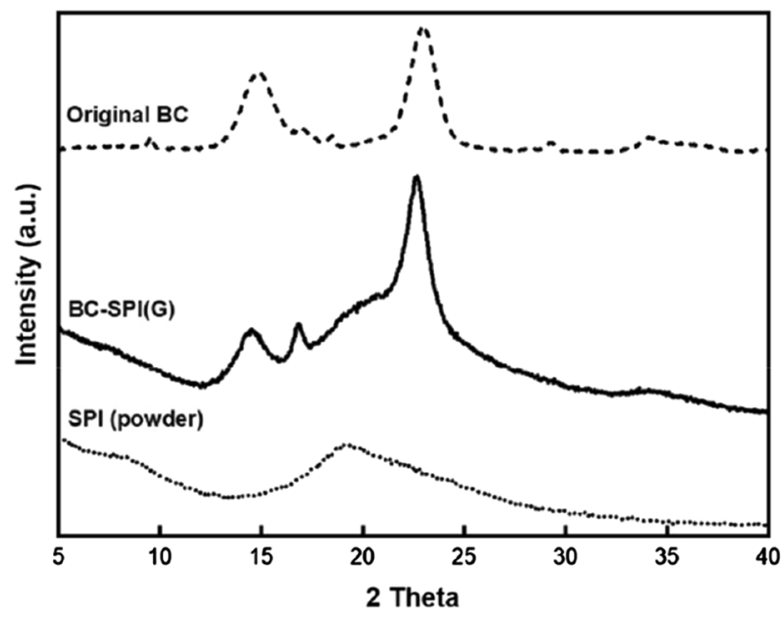

Fig. 10 XRD spectra of a original BC, BC-SPI(G), and SPI (powder); b original $\mathrm{BC}, \mathrm{BC}-\mathrm{MP}(\mathrm{G})$, and $\mathrm{MP}$ (powder) (production conditions for $\mathrm{BC}-\mathrm{SPI}(\mathrm{G})$ : fabric to liquor ratio of $1: 10$, SPI at an amount of $20 \mathrm{wt} \%$ of $\mathrm{BC}, 30 \mathrm{wt} \%$ of $\mathrm{BC}$ of

Table 4 Crystallinity degree of original BC, BC-SPI(G), and $\mathrm{BC}-\mathrm{MP}(\mathrm{G})$ (production conditions for $\mathrm{BC}-\mathrm{SPI}(\mathrm{G})$ : fabric to liquor ratio of $1: 10$, SPI at an amount of $20 \mathrm{wt} \%$ of $\mathrm{BC}$, $30 \mathrm{wt} \%$ of $\mathrm{BC}$ of glycerol; production conditions for $\mathrm{BC}$ $\mathrm{MP}(\mathrm{G})$ : fabric to liquor ratio of $1: 10, \mathrm{MP}$ at an amount of $50 \mathrm{wt} \%$ of BC, $30 \mathrm{wt} \%$ of BC of glycerol)

\begin{tabular}{ll}
\hline Sample & Crystallinity $(\%)$ \\
\hline Original BC & $82.6 \pm 3.6$ \\
BC-SPI $(G)$ & $68.3 \pm 2.4$ \\
BC-MP(G) & $71.6 \pm 5.8$ \\
\hline
\end{tabular}

$\mathrm{BC}$ nanostructure, possibly due to the crosslinking between SPI and BC, filling the fibrous structure of BC (Arfa et al. 2007). The BC fiber structure was not seen in the SEM image of BC-MP(G), though a densely coated surface was observed. This is attributed to the strong interaction between BC and MP (Liu et al. 2017). Moreover, the surface of $B C-M P(G)$ was relatively smoother than that of $\mathrm{BC}-\mathrm{SPI}(\mathrm{G})$. This might be related to the higher concentration of MP than that of BC-SPI $(G)$. The surface smoothness is an important factor because the user feels comfortable when using the $\mathrm{BC}$ bio-leather (Ramnath et al. 2011). From the results, it was confirmed that BC$\mathrm{MP}(\mathrm{G})$ would be more suitable than BC-SPI $(\mathrm{G})$ as a leather substitute. (b)

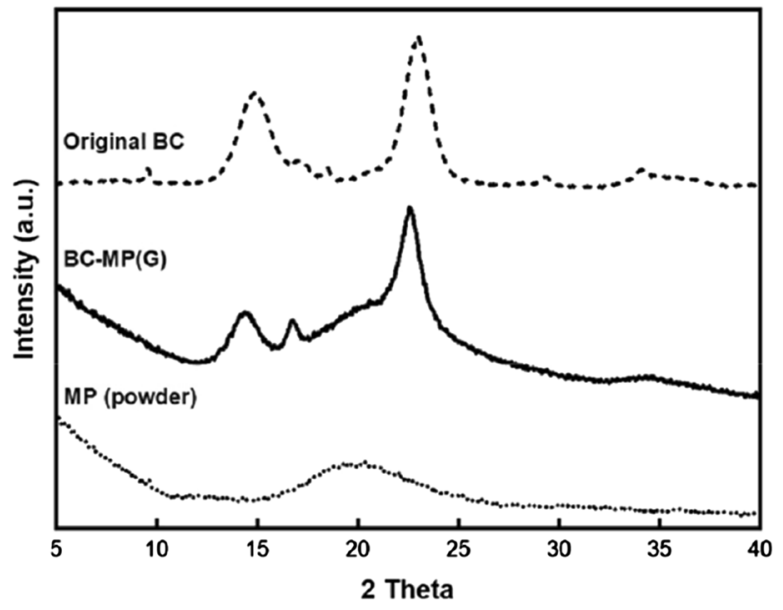

glycerol; production conditions for $\mathrm{BC}-\mathrm{MP}(\mathrm{G})$ : fabric to liquor ratio of 1:10, MP at an amount of $50 \mathrm{wt} \%$ of $\mathrm{BC}, 30 \mathrm{wt} \%$ of $\mathrm{BC}$ of glycerol)

EDX was used to provide both quantitative and qualitative information regarding the amount of proteins on the surface and inside $\mathrm{BC}$ bio-leathers. In Fig. 12, all three samples exhibit peaks of $\mathrm{C}$ and $\mathrm{O}$ elements, which were attributed to the $\mathrm{BC}$ component (Janpetch et al. 2016; Gutierrez et al. 2013), thus confirming the presence of the cellulose structure of BC. In the EDX spectrum of the original $\mathrm{BC}$, a negligible peak of Na element was observed due to the use of sodium hydroxide in the purification and swelling of BC (DeMello 2012). As shown in Table 5, the weight percentages of $\mathrm{Na}$ and $\mathrm{P}$ elements in $\mathrm{BC}$ $\mathrm{SPI}(\mathrm{G})$ were higher than those of $\mathrm{BC}-\mathrm{MP}(\mathrm{G})$. This was in accordance with a previous study in which $\mathrm{Na}$ and $\mathrm{P}$ were the distinctive markers of SPI (Sett et al. 2015). In addition, the equivalent $\mathrm{wt} \%$ of $\mathrm{S}$ element was detected in the EDX spectra of both BC-SPI(G) and BC-MP $(G)$ due to the presence of sulphureted amino acids in the protein (Porras-Saavedra et al. 2015). Based on the FT-IR, XRD, surface morphology, and EDX results, it was confirmed that the SPI and MP were successfully entrapped inside the $\mathrm{BC}$ bio-leather without significantly changing the chemical and crystalline structures of the original $\mathrm{BC}$. 

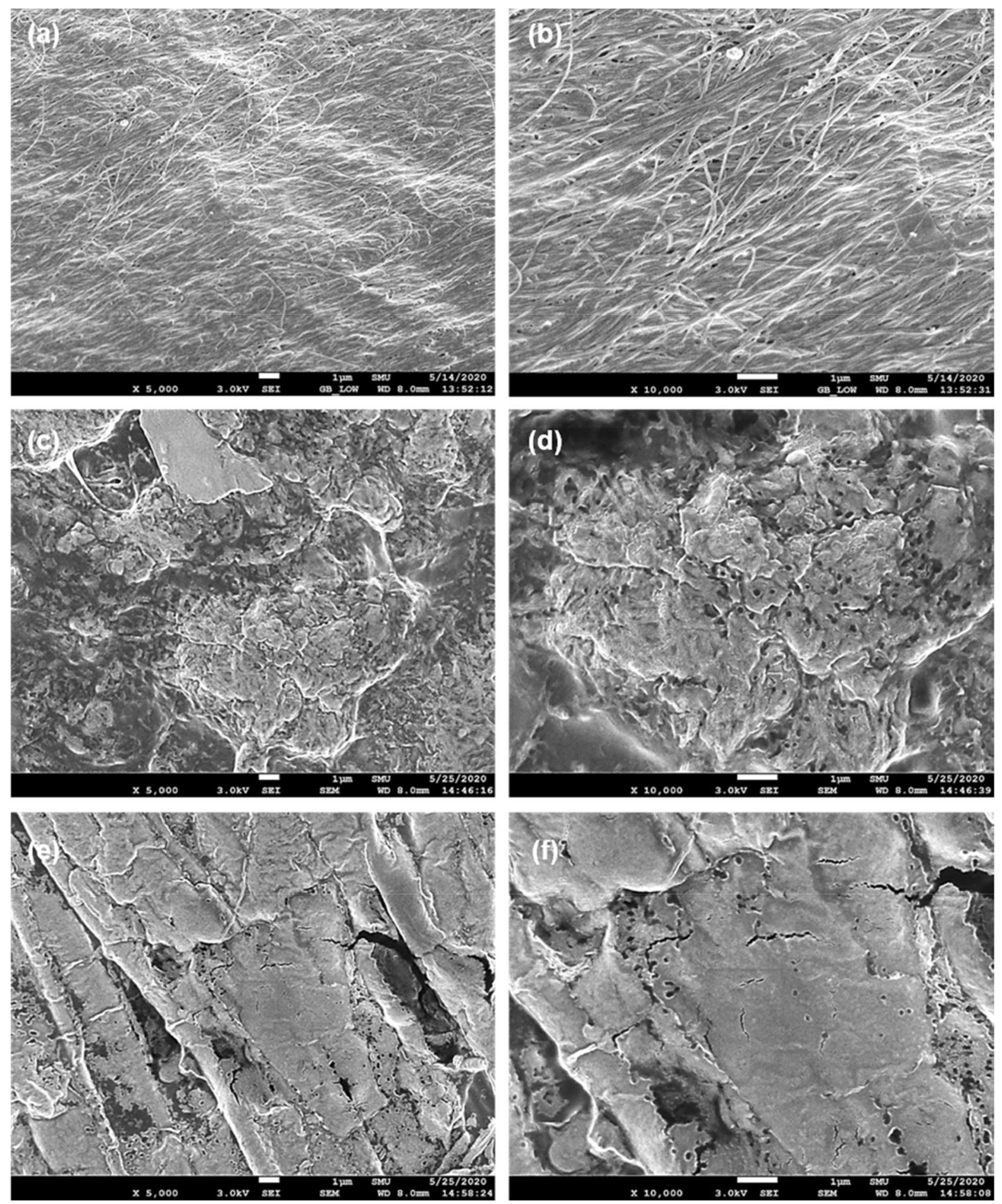

Fig. 11 SEM images of a, b original BC; c, d BC-SPI $(\mathrm{G})$; e, f $\mathrm{BC}-\mathrm{MP}(\mathrm{G})$ at 5000 and $10,000 \times$ magnification, respectively, with a scale bar of $1 \mu \mathrm{m}$ (production conditions for BC-SPI $(\mathrm{G})$ : fabric to liquor ratio of $1: 10$, SPI at an amount of $20 \mathrm{wt} \%$ of BC,

$30 \mathrm{wt} \%$ of $\mathrm{BC}$ of glycerol; production conditions for BC$\mathrm{MP}(\mathrm{G})$ : fabric to liquor ratio of $1: 10, \mathrm{MP}$ at an amount of $50 \mathrm{wt} \%$ of BC, $30 \mathrm{wt} \%$ of BC of glycerol) 
(a)
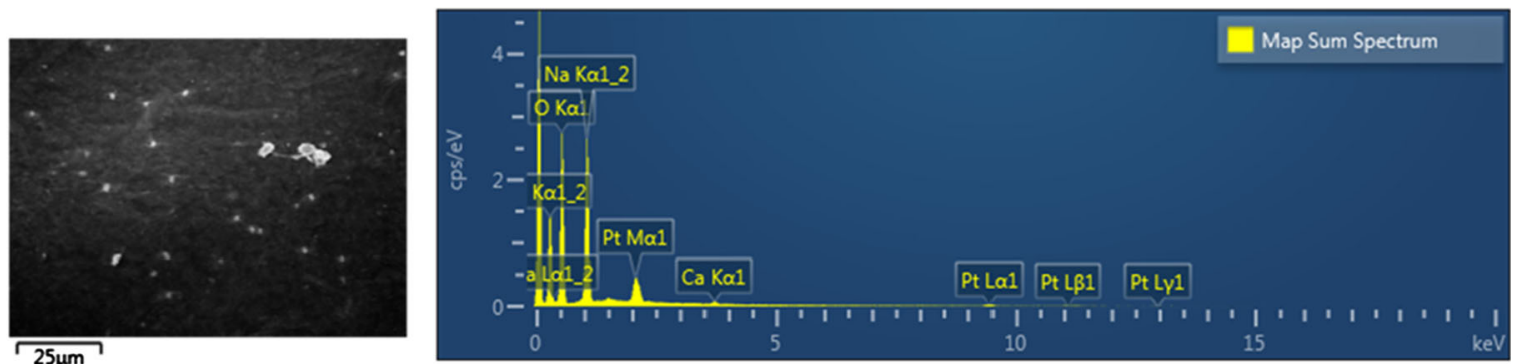

(b)
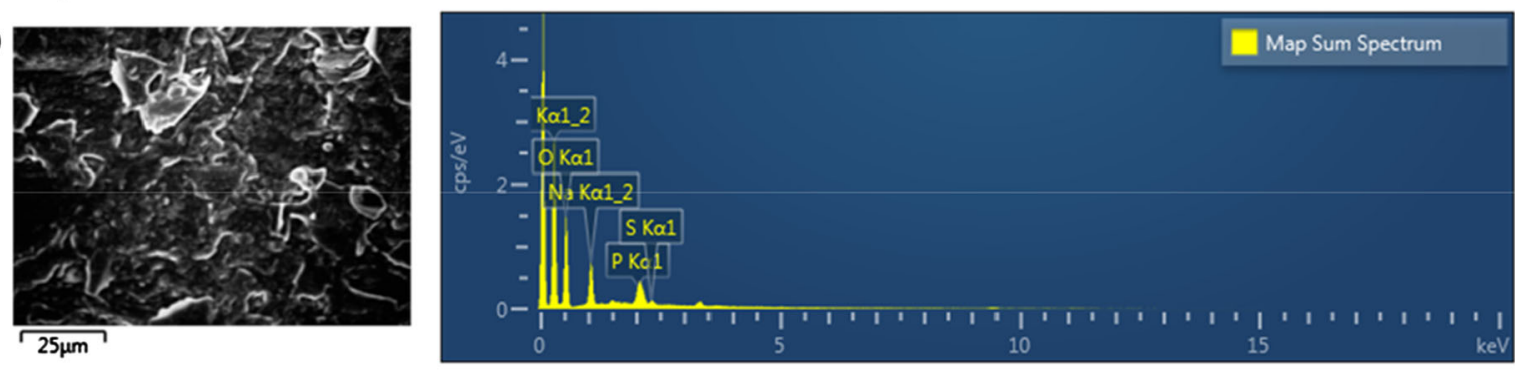

(c)
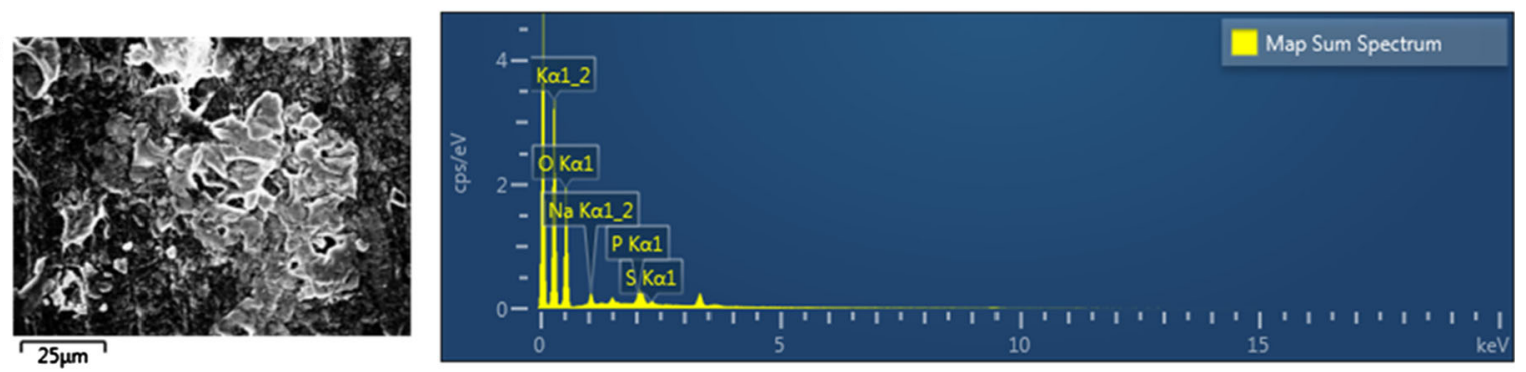

Fig. 12 EDX spectra of a original BC; b BC-SPI(G); c BC$\mathrm{MP}(\mathrm{G})$ (production conditions for $\mathrm{BC}-\mathrm{SPI}(\mathrm{G})$ : fabric to liquor ratio of $1: 10$, SPI at an amount of $20 \mathrm{wt} \%$ of BC, $30 \mathrm{wt} \%$ of BC

Table 5 Weight $\%$ of elements of original BC, BC-SPI $(\mathrm{G})$, and $\mathrm{BC}-\mathrm{MP}(\mathrm{G})$ (production conditions for $\mathrm{BC}-\mathrm{SPI}(\mathrm{G})$ : fabric to liquor ratio of $1: 10$, SPI at an amount of $20 \mathrm{wt} \%$ of $\mathrm{BC}$, $30 \mathrm{wt} \%$ of BC of glycerol; production conditions for BC$\mathrm{MP}(\mathrm{G})$ : fabric to liquor ratio of $1: 10, \mathrm{MP}$ at an amount of $50 \mathrm{wt} \%$ of BC, $30 \mathrm{wt} \%$ of BC of glycerol)

\begin{tabular}{llllll}
\hline Sample & \multicolumn{5}{l}{ Elements (wt\%) } \\
\cline { 2 - 6 } & $\mathrm{C}$ & $\mathrm{O}$ & $\mathrm{Na}$ & $\mathrm{P}$ & $\mathrm{S}$ \\
\hline Original BC & 5.76 & 5.18 & 1.36 & - & - \\
BC-SPI(G) & 6.27 & 3.71 & 0.48 & 0.03 & 0.03 \\
BC-MP(G) & 7.01 & 4.74 & 0.14 & 0.01 & 0.03 \\
\hline
\end{tabular}

\section{Conclusions}

This study aimed to develop eco-friendly BC bioleather and improve its durability by physical of glycerol; production conditions for $\mathrm{BC}-\mathrm{MP}(\mathrm{G})$ : fabric to liquor ratio of 1:10, MP at an amount of $50 \mathrm{wt} \%$ of $\mathrm{BC}, 30 \mathrm{wt} \%$ of $\mathrm{BC}$ of glycerol)

entrapment of plant-based proteins as reinforcing additive materials. For this purpose, SPI and MP were selected, and their amounts for $\mathrm{BC}$ bio-leather were determined to be 20 and $50 \mathrm{wt} \%$ of BC, respectively. The durability of BC bio-leather remarkably increased after the entrapment of two types of plant-based proteins. The WCAs of BC entrapped with both plantbased proteins and glycerol were improved by $40 \%$ compared to that of the original $\mathrm{BC}$. The highest tensile strength of approximately $13 \mathrm{~N} / \mathrm{mm}^{2}$ was obtained from BC-MP(G), which was better than that of cowhide leather. The flexibility and crease recovery of $\mathrm{BC}$ bio-leathers were also improved after the entrapment of plant-based proteins. After immersed in the wetting solution for $180 \mathrm{~min}$, the dimensional stability of BC-SPI $(\mathrm{G})$ and BC-MP(G) was improved by $14 \%$ and $22 \%$, respectively, compared to that of the original BC. The SPI and MP entrapped in BC bioleather were chemically detected by FT-IR, XRD, and 
EDX analyses, and the surface morphology of BCSPI $(G)$ and BC-MP $(G)$ was evaluated by SEM. These results confirmed successful entrapment of plantbased proteins inside $\mathrm{BC}$ without changing the chemical and crystalline structure of the original BC.

Therefore, this study demonstrated that the durability of BC bio-leather can be enhanced by physical entrapment of plant-based proteins such as SPI and MP. In particular, MP was effective in improving the durability of $\mathrm{BC}$ bio-leather. Moreover, BC$\mathrm{MP}(\mathrm{G})$ had lesser thickness, lighter weight, and higher strength compared to those of cowhide leather. It is expected that $\mathrm{BC}$ bio-leather, with its improved durability, can be a competitive bio-leather material for wide applications.

Funding This research was supported by the National Research Foundation of Korea (NRF) Grant funded by the Korean government (MSIT) (No. NRF-2019R1A2C1009217).

\section{Compliance with ethical standards}

Conflict of interest The authors declared no potential conflicts of interest with respect to the research, authorship, and/or publication of this article.

Open Access This article is licensed under a Creative Commons Attribution 4.0 International License, which permits use, sharing, adaptation, distribution and reproduction in any medium or format, as long as you give appropriate credit to the original author(s) and the source, provide a link to the Creative Commons licence, and indicate if changes were made. The images or other third party material in this article are included in the article's Creative Commons licence, unless indicated otherwise in a credit line to the material. If material is not included in the article's Creative Commons licence and your intended use is not permitted by statutory regulation or exceeds the permitted use, you will need to obtain permission directly from the copyright holder. To view a copy of this licence, visit http://creativecommons.org/licenses/by/4.0/.

\section{References}

Abbott NJ (1951) The measurement of stiffness in textile fabrics. Text Res J 21(6):435-441. https://doi.org/10.1177/ 004051755102100610

Arfa AB, Chrakabandhu Y, Preziosi-Belloy L, Chalier P, Gontard N (2007) Coating papers with soy protein isolates as inclusion matrix of carvacrol. Food Res Int 40(1):22-32. https://doi.org/10.1016/j.foodres.2006.07.011

Behera AK, Avancha S, Basak RK, Sen R, Adhikari B (2012) Fabrication and characterizations of biodegradable jute reinforced soy based green composites. Carbohydr Polym 88(1):329-335. https://doi.org/10.1016/j.carbpol.2011.12. 023
Bekatorou A, Plioni I, Sparou K, Maroutsiou R, Tsafrakidou P, Petsi T, Kordouli E (2019) Bacterial cellulose production using the Corinthian currant finishing side-stream and cheese whey: process optimization and textural characterization. Foods 8(6):193. https://doi.org/10.3390/ foods 8060193

Chhavi DKM, Singh VK, Chauhan S, Jain N (2017) Soy protein based green composite: a review. Res Rev J Mater Sci 5(2):66-77. https://doi.org/10.4172/2321-6212.1000171

Cielecka I, Szustak M, Kalinowska H, Gendaszewska-Darmach E, Ryngajllo M, Maniukiewicz W, Bielecki S (2019) Glycerol-plasticized bacterial nanocellulose-based composites with enhanced flexibility and liquid sorption capacity. Cellulose 26:5409-5426. https://doi.org/10. 1007/s10570-019-02501-1

DeMello JA (2012) Bacterial cellulose templates for nano-hydroxyapatite fiber synthesis. Dissertation, University of Western Ontario. https://ir.lib.uwo.ca/etd/397

De Santa Costa AF, Rocha MAV, Sarubbo LA (2017) Reviewbacterial cellulose: an ecofriendly biotextile. IJTFT 7(1):11-26

Epure V, Griffon M, Pollet E, Averous L (2011) Structure and properties of glycerol-plasticized chitosan obtained by mechanical kneading. Carbohydr Polym 83(2):947-952. https://doi.org/10.1016/j.carbpol.2010.09.003

Feng Y, Zhang X, Shen Y, Yoshino K, Feng W (2012) A mechanically strong, flexible and conductive film based on bacterial cellulose/graphene nanocomposite. Carbohydr Polym 87(1):644-649. https://doi.org/10.1016/j.carbpol. 2011.08.039

Finimundy TC, Dillon AJP, Henriques JAP, Ely MR (2014) A review on general nutritional compounds and pharmacological properties of the Lentinula edodes mushroom. Food Nutr Sci 5(5):1095-1105. https://doi.org/10.4236/fns. 2014.512119

Garcia C, Prieto MA (2019) Bacterial cellulose as a potential bioleather substitute for the footwear industry. Microb Biotechnol 12(4):582-585. https://doi.org/10.1111/17517915

Gu W, Liu X, Li F, Shi SQ, Xia C, Zhou W, Zhang D, Gong S, Li J (2019) Tough, strong, and biodegradable composite film with excellent UV barrier performance comprising soy protein isolate, hyperbranched polyester, and cardanol derivative. Green Chem 21(13):3651-3665. https://doi. org/10.1039/C9GC01081E

Guo Y, Zhang X, Hao W, Xie Y, Chen L, Li Z, Zhu B, Feng X (2018) Nano-bacterial cellulose/soy protein isolate complex gel as fat substitutes in ice cream model. Carbohydr Polym 198:620-630. https://doi.org/10.1016/j.carbpol. 2018.06.078

Gutierrez J, Fernandes SCM, Mondragon I, Tercjak A (2013) Multifunctional hybrid nanopapers based on bacterial cellulose and sol-gel synthesized titanium/vanadium oxide nanoparticles. Cellulose 20:1301-1311. https://doi.org/10. 1007/s10570-013-9898-2

Han J, Shim E, Kim HR (2018) Effects of cultivation, washing, and bleaching conditions on bacterial cellulose fabric production. Text Res J 89(6):1094-1104. https://doi.org/ $10.1177 / 0040517518763989$

Indrarti L, Indriyati Syampurwadi A, Pujiastuti S (2016) Physical and mechanical properties of modified bacterial 
cellulose composite films. AIP Conf Proc 1711:050007. https://doi.org/10.1063/1.4941633

Janpetch N, Saito N, Rujiravanit R (2016) Fabrication of bacterial cellulose- $\mathrm{ZnO}$ composite via solution plasma process for antibacterial applications. Carbohydr Polym 148:335-344. https://doi.org/10.1016/j.carbpol.2016.04. 066

Kanagaraj J, Velappan KC, Chandra Babu NK, Sadulla S (2006) Solid wastes generation in the leather industry and its utilization for cleaner environment: a review. J Sci Ind Res 65:541-548

Kayode RMO, Olakulehin TF, Adedeji BS, Ahmed O, Aliyu TH, Badmos AHA (2015) Evaluation of amino acid and fatty acid profiles of commercially cultivated oyster mushroom (Pleurotus sajor-caju) grown on gmelina wood waste. Niger Food J 33(1):18-21. https://doi.org/10.1016/j. nifoj.2015.04.001

Kim DS, Kim YW, Kim KJ, Shin HJ (2017) Research trend and product development potential of fungal mycelium-based composite materials. KSBB J 32(3):174-178. https://doi. org/10.7841/ksbbj.2017.32.3.174

Kim H, Yi J-Y, Kim B-G, Song JE, Jeong H-J, Kim HR (2020a) Development of cellulose-based conductive fabrics with electrical conductivity and flexibility. PLoS ONE 15(6):e0233952. https://doi.org/10.1371/journal.pone. 0233952

Kim H, Song JE, Silva C, Kim HR (2020b) Production of conductive bacterial cellulose-polyaniline membranes in the presence of metal salts. Text Res J 90(13-14):1517-1526. https://doi.org/10.1177/0040517519893717

Kokoszka S, Debeaufort F, Hambleton A, Lenart A, Voilley A (2010) Protein and glycerol contents affect physicochemical properties of soy protein isolate-based edible films. Innov Food Sci Emerg Technol 11(3):503-510. https://doi.org/10.1016/j.ifset.2010.01.006

Li S, Huang D, Zhang B, Xu X, Wang M, Yang G, Shen Y (2014) Flexible supercapacitors based on bacterial cellulose paper electrodes. Adv Energy Mater 4(10):1301655. https://doi.org/10.1002/aenm.201301655

Lima HLS, Goncalves C, Cerqueira MA, Do Nascimento ES, Gama MF, Rosa MF, De Fatima Borges M, Pastrana LM, Santa Brigida AI (2018) Bacterial cellulose nanofiberbased films incorporating gelatin hydrolysate from tilapia skin: production, characterization and cytotoxicity assessment. Cellulose 25:6011-6029. https://doi.org/10.1007/ s10570-018-1983-0

Liu J, Lu X, Wu C (2013) Effect of preparation methods on crystallization behavior and tensile strength of poly(vinylidene fluoride) membranes. Membranes 3(4):389-405. https://doi.org/10.3390/membranes3040389

Liu X, Souzandeh H, Zheng Y, Xie Y, Zhong WH, Wang C (2017) Soy protein isolate/bacterial cellulose composite membranes for high efficiency particulate air filtration. Compos Sci Technol 138:124-133. https://doi.org/10. 1016/j.compscitech.2016.11.022

Muller D, Rambo CR, Porto LM, Schreiner WH, Barra GMO (2013) Structure and properties of polypyrrole/bacterial cellulose nanocomposites. Carbohydr Polym 94(1): 655-662. https://doi.org/10.1016/j.carbpol.2013.01.041

Ou S, Kwok KC, Kang Y (2004) Changes in in vitro digestibility and available lysine of soy protein isolate after formation of film. J Food Eng 64(3):301-305. https://doi.org/10.1016/j. jfoodeng.2003.10.013

Park YA, Bak WC, Ka KH, Koo CD (2017) Comparative analysis of amino acid content of Lentinula edodes, a new variety of shiitake mushroom, in 'Poongnyunko'. J Mushrooms 15(1):31-37. https://doi.org/10.14480/JM.2017.15. 1.31

Pang H, Zhao S, Qin T, Zhang S, Li J (2019) High-performance soy protein isolate-based film synergistically enhanced by waterborne epoxy and mussel-inspired poly(dopamine)decorated silk fiber. Polymers 11(10):1536. https://doi.org/ 10.3390/polym11101536

Porras-Saavedra J, Palacios-Gonzalez E, Lartundo-Rojas L, Garibay-Febles V, Yanez-Fernandez J, Hernandez-Sanchez H, Gutierrez-Lopez G, Alamilla-Beltran L (2015) Microstructural properties and distribution of components in microparticles obtained by spray-drying. J Food Eng 152:105-112. https://doi.org/10.1016/j.jfoodeng.2014.11. 014

Qi G, Li N, Wang D, Sun XS (2016) Development of HighStrength Soy Protein Adhesives Modified with Sodium Montmorillonite Clay. J Am Oil Chem Soc 93(11):1509-1517. https://doi.org/10.1007/s11746-0162890-x

Ramnath V, Sekar S, Sankar S, Sastry TP (2011) Preparation and partial characterization of composite films containing soya protein and sago starch. Int $\mathrm{J}$ Pharm Biol Sci 1(4):577-585

Rhim JW, Mohanty KA, Singh SP, Ng PKW (2006) Preparation and properties of biodegradable multilayer films based on soy protein isolate and poly(lactide). Ind Eng Chem Res 45(9): 3059-3066. https://doi.org/10.1021/ie051207+

Senapati US, Sarkar D (2014) Characterization of biosynthesized zinc sulphide nanoparticles using edible mushroom Pleurotuss ostreatu. Indian J Phys 88(6):557-562. https:// doi.org/10.1007/s12648-014-0456-Z

Sett S, Lee MW, Weith M, Pourdeyhimi B, Yarin AL (2015) Biodegradable and biocompatible soy protein/polymer/ adhesive sticky nano-textured interfacial membranes for prevention of esca fungi invasion into pruning cuts and wounds of vines. J Mater Chem B 3(10):2147-2162. https://doi.org/10.1039/C4TB01887G

Silverman J (2018) Development and testing of myceliumbased composite materials for shoe sole applications. Dissertation, University of Delaware

Song JE, Su J, Loureiro A, Martins M, Cavaco-Paulo A, Kim HR, Silva C (2017) Ultrasound-assisted swelling of bacterial cellulose. Eng Life Sci 17(10):1108-1117. https:// doi.org/10.1002/elsc.201700085

Song JE, Silva C, Cavaco-Paulo A, Kim HR (2019) Functionalization of bacterial cellulose nonwoven by poly(fluorophenol) to improve its hydrophobicity and durability. Front Bioeng Biotechnol 7:332. https://doi.org/10.3389/ fbioe.2019.00332

Song JE, Cavaco-Paulo A, Silva C, Kim HR (2020) Improvement of bacterial cellulose nonwoven fabrics by physical entrapment of lauryl gallate oligomers. Text Res J 90(2):166-178. https://doi.org/10.1177/0040517519862886

Stepanova V, Kelar J, Slavicek P, Chlupova S, Stupavska M, Jurmanova J, Cernak M (2017) Surface modification of natural leather using diffuse ambient air plasma. Int $\mathbf{J}$ 
Adhes Adhes 77:198-203. https://doi.org/10.1016/j. ijadhadh.2017.05.004

Sudha TB, Thanikaivelan P, Aaron KP, Krishnaraj K, Chandrasekaran B (2009) Comfort, chemical, mechanical, and structural properties of natural and synthetic leathers used for apparel. J Appl Polym Sci 114(3):1761-1767. https:// doi.org/10.1002/app.30589

Tian H, Wu W, Guo G, Gaolun B, Jia Q, Xiang A (2012) Microstructure and properties of glycerol plasticized soy protein plastics containing castor oil. J Food Eng 109(3):496-500. https://doi.org/10.1016/j.foodeng.2011. 10.033

Tian H, Guo G, Fu X, Yao Y, Yuan L, Xiang A (2018) Fabrication, properties and applications of soy-protein-based materials: a review. Int J Biol Macromol 120A:475-490. https://doi.org/10.1016/j.ijbiomac.2018.08.110

Tian Y, Zhao Y, Huang J, Zeng H, Zheng B (2016) Effects of different drying methods on the product quality and volatile compounds of whole shiitake mushrooms. Food Chem 197A:714-722. https://doi.org/10.1016/j.foodchem.2015. 11.029

Vigentini I, Fabrizio V, Dellaca F, Rossi S, Azario I, Mondin C, Benaglia M, Foschino R (2019) Set-up of bacterial cellulose production from the genus Komagataeibacter and its use in a gluten-free bakery product as a case study. Front Microbiol 10:1953. https://doi.org/10.3389/fmicb.2019. 01953

Wang L, Li J, Zhang S, Shi J (2016) Preparation and characterization of all-biomass soy protein isolate-based film enhanced by epoxy castor oil acid sodium and hydroxypropyl cellulose. Materials 9(3):193. https://doi.org/10. 3390/ma9030193

Wang X, Ullah N, Sun X, Guo Y, Chen L, Li Z, Feng X (2017) Development and characterization of bacterial cellulose reinforced biocomposite films based on protein from buckwheat distiller's dried grains. Int J Biol Macromol 96:353-360. https://doi.org/10.1016/j.ijbiomac.2016.11. 106

Wen X, Zheng Y, Wu J, Wang LN, Yuan Z, Peng J, Meng H (2015) Immobilization of collagen peptide on dialdehyde bacterial cellulose nanofibers via covalent bonds for tissue engineering and regeneration. Int $\mathrm{J}$ Nanomed 10:4623-4637. https://doi.org/10.2147/IJN.S84452
Wu Y, Cai L, Wang C, Mei C, Shi SQ (2018) Sodium hydroxide-free soy protein isolate-based films crosslinked by pentaerythritol glycidyl ether. Polymers (Basel) 10(12):1300. https://doi.org/10.3390/polym10121300

Xie Y, Niu X, Yang J, Fan R, Shi J, Ullah N, Feng X, Chen L (2020) Active biodegradable films based on the whole potato peel incorporated with bacterial cellulose and curcumin. Int J Biol Macromol 150(1):480-491. https://doi. org/10.1016/j.ijbiomac.2020.01.291

Xu X, Song K, Xing B, Hu W, Ke Q, Zhao Y (2019) Thermaltenacity-enhanced and biodegradable textile sizes from cellulose nanocrystals reinforced soy protein for effective yarn coating. Ind Crop Prod 140:111701. https://doi.org/ 10.1016/j.indcrop.2019.111701

Yang H, Yang S, Kong J, Dong A, Yu S (2015) Obtaining information about protein secondary structures in aqueous solution using Fourier transform IR spectroscopy. Nat Protoc 10:382-396. https://doi.org/10.1038/nprot.2015. 024

Yin SW, Tang CH, Wen QB, Yang XQ (2007) Properties of cast films from hemp (Cannabis sativa L.) and soy protein isolates. A comparative study. J Agric Food Chem 55(18):7399-7404. https://doi.org/10.1021/jf071117a

Zarlok J, Smiechowski K, Mucha K, Tecza A (2014) Research on application of flax and soya oil for leather fatliquoring. J Cleaner Prod 65:583-589. https://doi.org/10.1016/j. clepro.2013.07.044

Zhang X, Zhou J, Chen J, Li B, Li Y, Liu S (2020) Edible foam based on pickering effect of bacterial cellulose nanofibrils and soy protein isolates featuring interfacial network stabilization. Food Hydrocoll 100:105440. https://doi.org/10. 1016/j.foodhyd.2019.105440

Zhou Z, Zheng H, Wei M, Huang J, Chen Y (2008) Structure and mechanical properties of cellulose derivatives/soy protein isolate blends. J Appl Polym Sci 107(5):3267-3274. https://doi.org/10.1002/app.27323

Publisher's note Springer Nature remains neutral with regard to jurisdictional claims in published maps and institutional affiliations. 